\title{
New AMS dates from the Sub-Neolithic sites in the Southern Buh area (Ukraine) and problems in the Buh-Dnister Culture chronology
}

\author{
Dmytro Haskevych ${ }^{1}$, Eiko Endo ${ }^{2}$, Dai Kunikita ${ }^{3}$, and Olexandr Yanevich ${ }^{1}$ \\ 1 Institute of Archaeology of NAS of Ukraine, Kyiv, UA \\ dmytro.haskevych@gmail.com; janevic_a@ukr.net \\ 2 Meiji University, Tokyo, JP \\ endosalt@yahoo.co.jp \\ 3 The University of Tokyo, Tokyo, JP \\ dkunikita@yahoo.co.jp
}

\begin{abstract}
Ideas about the origin of the Buh-Dnister Culture under the influence of the Danube Early Neolithic were questioned by series of radiocarbon dates falling into the second half of the $7^{\text {th }}$ millennium BC measured on bones at the Kyiv laboratory in 1998-2004. To start addressing this problem, 11 AMS dates on organic inclusions in the ceramic paste and charred residues on the surface of vessels were obtained at the Tokyo University laboratory. Apart from two heavily overestimated values, measured on samples with very low carbon content, they fall into the range of the $60^{\text {th }}-46^{\text {th }}$ century BC that correspond better to the primary views of this chronology. However, the issues of the time and direction of spreading of the first pottery in the region need further research.
\end{abstract}

KEY WORDS - Neolithic; Buh-Dnister culture; radiocarbon dating; pottery; stratigraphy

\section{Novi AMS datumi iz sub-neolitskih najdišč na območju južnega dela reke Bug (Ukrajina) in težave s kronologijo kulture Bug-Dnester}

IZVLEČEK - Zaradi vrste radiokarbonskih datumov, ki sodijo v čas druge polovice 7. tisočletja pr. $n$. št. in so jih izmerili na kosteh v Kijevskem laboratoriju med leti 1998 do 2004, smo podvomili v zamisli o izvoru kulture Bug - Dnester pod vplivom Donavskega zgodnjega neolitika. Da bi lahko razrešili to vprašanje, smo v univerzitetnem laboratoriju v Tokiju pridobili 11 AMS datumov iz organskih vključkov v lončarskih masah in zoglenelih organskih ostankov na površinah posod. Razen dveh izredno precenjenih vrednosti, ki smo jih izmerili na vzorcih z nizko vsebnostjo ogljika, padejo datumi v razpon od 60. do 46. stoletja pr. n. št., kar je bolj v skladu s prvotnimi stališč o tej kronologiji. Ne glede na te rezultate pa bo potrebno čas in smer širitve prve lončenine v tej regiji še dodatno preučiti.

KLJUČNE BESEDE - neolitik; kultura Bug - Dnester; radiokarbonsko datiranje; lončenina; stratigrafija 


\section{Introduction}

The Neolithisation process, defined as the spread of sedentary lifestyle and farming is one of the main issues in prehistory. In Eastern Europe, a key area for its study is the basin of the Dnister ${ }^{1}$ and Southern Buh Rivers, which flow into the Black Sea to the east of the Carpathians. There, Neolithic farming incomers from the Balkan-Danube area directly contacted with indigenous groups. The evidence of such interaction, marked in archaeological records from the local sites, became a reason for distinguishing the Buh-Dnister Culture (henceforth, BDC).

To make the timing and the route of dispersal of crops in Ukraine clear a special archaeobotanical project was carried out by a joint Japanese-Ukrainian team in 2016-20192. Within its framework early published information about imprints of cultivated plants on the BDC pottery has been checked. Re-identification using a refined impression method has not found any reliable imprints of cereals and pulses (Endo et al. in prep.). This confirms that in terms of the availability model of the agricultural transition (Zvelebil, Rowley-Conwy 1984; 1986) the BDC bearers should likely be recognised as a community at the availability stage throughout their existence. Therefore, following some researchers (e.g., Dergachev et al. 1991), it would be more correct to call the culture not Neolithic but Para-Neolithic or SubNeolithic. These terms have long been used by archaeologists from Poland, Finland, and the Baltic states to refer to hunting-gathering semi-mobile societies manufacturing pottery and polished stone tools. Recently, Oleksandr Gorelik asserts the need for the consistent use of such terms regarding the cultures of $7^{\text {th }}-6^{\text {th }}$ millennium BC in the southern part of Eastern Europe (Gorelik 2019). Thus, in the mentioned time, the 'real' Neolithic with a farming economy is represented here only by groups of incomers from the Balkans-Danube-Carpathians region, correlated with the cultures of Cris and Linear-Band Pottery, and in the $5^{\text {th }}$ millennium BC the Trypillia Culture.

In the course of the project, the team was confronted with questions about the age of vessels, on the surfaces of which they were looking for the imprints.
But, in the case of the BDC, it could not be answered exactly, since both its relative chronology and absolute dates have caused heated discussion during the last two decades. As an attempt to start clarifying this problem, two samples of carbonized crust and nine samples of organic inclusions in ceramic paste have been measured using the AMS method at the Radiocarbon Dating Laboratory of the University Museum of the University of Tokyo.

\section{Overview of the BDC chronology research}

The BDC area covers part of both the Southern Buh and the Dnister River basins within the forest-steppe and steppe zones in present-day Ukraine and Moldova (Fig. 1). To date, about 70 monuments of the culture are known there. Only 15 of those are in the Dnister area, the rest are in the Southern Buh area. A few characteristic BDC vessels were also found on some sites of other cultures in neighbouring regions, where they are considered as so-called 'imported' goods. According to the specifics of the material, three local variants of the culture are distinguished - in the Buh forest-steppe area, in the Buh steppe area, and the Dnister area.

\section{Field research and source criticism}

Sub-Neolithic materials were discovered for the first time in the Southern Buh area between 1928-1931. But they were not published properly and almost all were lost during World War II. The BDC was distinguished by Valentyn Danylenko during his research in the forest-steppe part of the Buh area in 19491961 (Danilenko 1969.46-174). The majority of the BDC sites situated on the Dnister riverbanks were researched by Vsevolod Markevich in the north of Moldova in the 1960s (Markevich 1974) and Valentin Dergachev, Olga Larina, and Klaus-Peter Wechler in the 1990s (Larina et al. 1997; Wechler et al. 1998; Larina 2006). Mykola Tovkailo has excavated several BDC sites in the Southern Buh steppe since 1980 (Tovkajlo 1996; Tovkaylo 2005; 2010; 2014). Leonid Zalizniak (Zaliznyak et al. 2013.194-257), Dmytro Haskevych (2006; Gaskevych, Zhuravlev 2008; Czerniak et al. 2013), and Dmytro Kiosak (2016. 137-141; Kiosak, Salavert 2018.120-122) have investigated the BDC in the Southern Buh forest-steppe in the $21^{\text {st }}$ century.

\footnotetext{
1 In the article all Ukrainian geographical names and derived names of archaeological monuments and cultures are given according to their writing in Ukrainian, not the Russian commonly used earlier. The same applies to the names of researchers, except for the references. Out of a dozen ways of romanizing the Ukrainian alphabet, the standard adopted by Ukrainian government in 2010 is used here.

2 The work was supported by the Japan Grants-in-Aid for Scientific Research Program (KAKENHI Research Project 16K03166, principal investigator - Eiko Endo).
} 
Most of the researched monuments are located in a river floodplain on the edge of periodically flooded river terraces, or just on riverbanks and islands. Often, they are near mouths of tributaries - brooks and small rivers. A lot of the sites in the Buh area are near river rapids. In those places, rivers break over the granite ridges of the Ukrainian Crystalline Massif forming canyons with steep sides. The shallow but wide and fast rivers flow on among large granite blocks and islands. Such areas are well-suited for fishing. The convenient places on the banks were settled many times. As a result, monuments with thick cultural levels, rich in finds of diverse time and cultures, arose there.

The conditions of the rapid parts of the river valleys promote the construction of hydroelectric power stations at such locations. In the BDC area, 13 stations are built on the Buh and its tributaries, and three stations

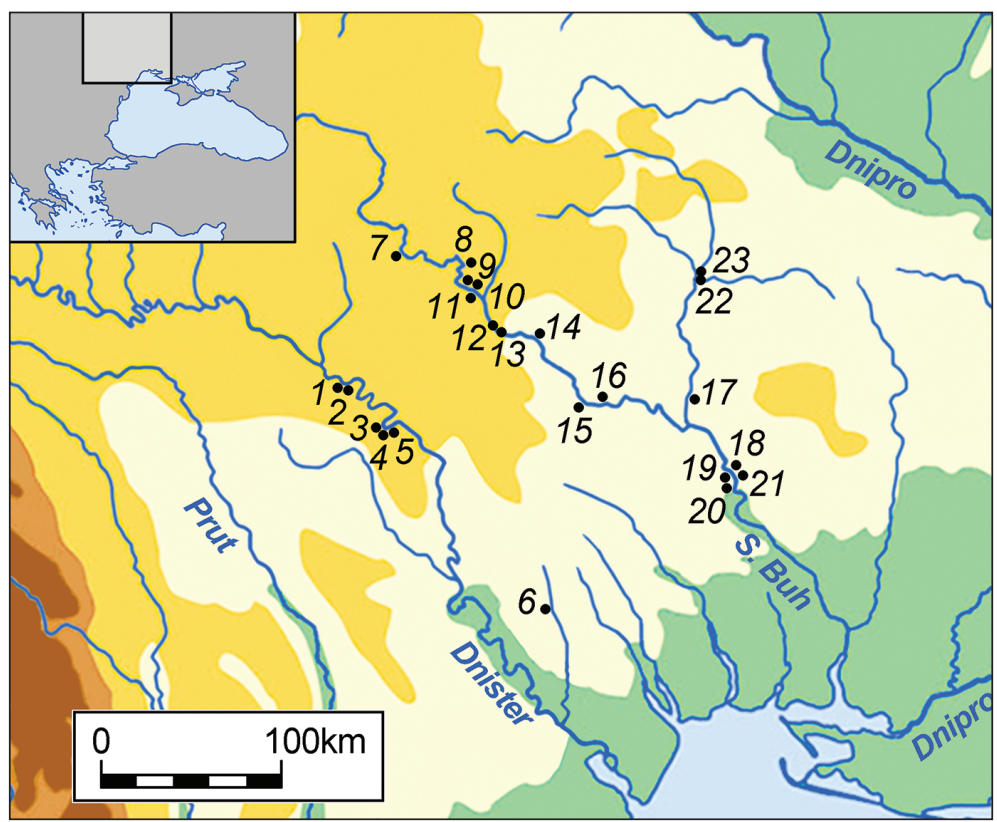

Fig. 1. Map of the ${ }^{14} C$ dated BDC sites. 1 Tătărăuca Nouă XIV; 2 Tă tărăuca Nouă XV; 3 Soroca V; 4 Soroca II; 5 Soroca III; 6 Hirzhove; 7 Pechera I; 8 Ziankivtsi II; 9 Sokiltsi II; 10 Sokiltsi I; 11 Hlynske I; 12 Mytkiv Ostriv; 13 Bazkiv Ostriv; 14 Shumyliv-Cherniatka; 15 Savran; 16 Melnychna Krucha; 17 Mykolyna Broiaka; 18 Puhach II; 19 Gard III; 20 Gard; 21 Tashlyk II; 22 Dobrianka 3; 23 Dobrianka 1. on the Dnister. Constructions of several of these were preceded by archaeological explorations of the terrain before it was submerged. Danylenko's fieldwork was carried out for this reason. As a result, almost all of the important large-scale excavated BDC sites are submerged now. Moreover, many identified but not investigated settlements, as well as the territories most suitable for occupation, were submerged on both the Southern Buh and Dnister. The current excavation by Tovkailo at the site of Gard on the Southern Buh River is being done as it will be submerged in the future, too. In general, the situation reminds us of the loss of the famous original settlements and burial grounds in the Iron Gates area on the Danube, although repeated many times here.

The specificity of the rescue excavations has determined the state of archaeological records. In the Soviet Union, such field works were carried out in a hurry, obeyed the needs of construction, not science. The Soviet mentality of the administration and archaeologists was aimed at obtaining impressive quantitative rather than quality results. As such, scientists frequently preferred the excavation of monuments with the largest number of finds, not possibly more interesting archaeological contexts. Many of those sites are places of continual occupation, oversaturated with mixed materials from different peri- ods. The aim of doing the work more cheaply and quickly uncovering a wide area often led to the excavation of settlements, where the cultural layers lay at a low depth and therefore were heavily damaged by nature and man. Some collections include finds from the surface of absolutely destroyed monuments. In contrast, sites with 'pure' cultural layers poorly loaded by finds, but well-preserved by thick sediment deposits, were investigated in a small area.

Insufficient funding and the atmosphere of haste and negligence in research often led to the involvement of unskilled personnel, non-compliance with fieldwork procedures, and a deficiency of field documentation - lack of drawings of excavations and cross-sections, plans of sites, photos, and depth measurements. Later, this was followed by the loss of a considerable portion of the finds, mainly faunal remains and pottery. The publication of the materials was also incomplete and tendentious. For many sites, no topographical plans, drawings of excavations, figures of the majority of finds, or statistics were provided. Errors and contradictions in records and the ignoring of facts not fitting the paradigms of the time are quite frequent (Gaskevych 2013.6-9; 2015). Moreover, archaeologists have been disregarding any critical analysis of the sources for decades and have made their conclusions based on the study of 
artificially sorted collections and imperfect publications.

The building of hydroelectric power stations has not only submerged many monuments but also changed the water regime of the Southern Buh and Dnister rivers with regard to their stopping spring floods, thus eroding the banks. This has led to covering of the floodplain with trees and bushes. Due to this the discovery of new sites has become more complicated. One of this article's authors has found only a few new BDC sites suitable for excavation during almost two decades of prospecting. The slow accumulation of new applicable materials makes it necessary to work with old collections of destroyed and submerged monuments, despite their imperfections. Therefore, the absolute dating of such sites is an important task for current researchers.

\section{History of absolute dating}

The radiocarbon dating of the BDC began at the end of the 1960s when four dates for two monuments located near the city of Soroca on the Dnister River were measured at the Berlin laboratory (Quitta, Kohl 1969.250). Twenty years later, a sample from the settlement of Puhach II was measured at the Kyiv laboratory (Tovkajlo 1996.24) and a sample from the Hirzhove site at the Leningrad one (Stanko, Svezhentsev 1988.117). In 1997-1998, Gliwice and Kiel radiocarbon laboratories provided three conventional and five AMS dates for three monuments from the territory of Moldova, respectively (Larina et al. 1997.109; Wechler 2001.29-30). In 1997-2004, 30 conventional dates of the Buh area sites, investigated in the 1950-1980s, were measured at the Kyiv laboratory (Videiko, Kovalyukh 1998; Burdo 2002; Kotova 2003.130-133, 139-140; Manko 2006.1819). Another 20 conventional dates measured at the Kyiv laboratory and four AMS dates obtained at the Groningen and Oxford ones in 2005-2010 are connected with the recent work at sites Dobrianka-1, Dobrianka-3 (Zaliznyak, Manko 2004.141, 145; Biagi et al. 2007.27; Lillie et al. 2009.260), Gard (Tovkaylo 2010.214; 2014.231), and Tashlyk II (Fomenko et al. 2014.Tab. 3). More recently, two AMS dates have been measured at the Poznan laboratory on charcoal from a new excavation on the site of Melnychna Krucha (Kiosak, Salavert 2018.122).

At present, in sum 71 dates measured on samples from the BDC sites have been published (Tab. 1; Fig.
1). Among these, four dates of the so-called 'aceramic' sites Ziankivtsi II and Soroca II, levels 2 and 3, and the bottom level in the Gard site are confidently linked to the Mesolithic. Two other dates measured directly on the early Trypillian pottery from so-called 'syncretic' complex in Gard are confidently linked to the Eneolithic. Eight more dates turned out to be very much older or younger than expected, and are considered 'non-Neolithic' without discussion. They show real cultural stratigraphy in the sites, where finds of different periods are mixed. It should be emphasized, that all the eight were measured at European laboratories (and are almost half the dates obtained there for BDC sites) and were published by European researchers (Wechler 2001. 29-30; Biagi et al. 2007.27; Lillie et al. 2009.260). In contrast, in a large set of 51 Kyiv dates, clear 'nonNeolithic' values are not present at all. These results are never even mentioned by Ukrainian authors, which is especially suspect. It seems the problem concerning stratigraphy was either unnoticed or carefully hidden by these researchers.

Possible belonging to the BDC as such is thus supposed for only 57 dates, which may be subjected to further analysis. A high limit of the oldest date reaches the $65^{\text {th }}$ century $\mathrm{BC}$, and a low limit of the youngest date the $47^{\text {th }}$ century $\mathrm{BC}^{3}$. But there is no concordance of opinion concerning the timeframe of the BDC. After the publication of a large series of Kyiv dates in 1998, the specialists divided into two opposing camps. This cleavage was deepened by new Kyiv dates over the next decade. One camp approved the dates pointing to the $60^{\text {th }}-47^{\text {th }}$ centuries $\mathrm{BC}$, measured abroad and at the Kyiv laboratory before 1998. And the other thinks that the set of new Kyiv dates, measured since 1998 and pointing to the $65^{\text {th }}-50^{\text {th }}$ centuries $\mathrm{BC}$ is right. The terms 'old chronology' and 'new chronology' thus began to be used in publications. The reason for scepticism regarding the 'new' dates is not only their inconsistency with the time of the BDC start and end measured at the European laboratories, but their inconsistency with the relative chronology of the culture, too.

\section{Relative chronology}

The first BDC periodization was proposed by Danylenko (1969). He divided the culture into seven phases, grouped into three periods (Tab. 2). In constructing this scheme he relied on the specificity of the pottery, which was regarded as the main chro-

3 All ${ }^{14} \mathrm{C}$ dates in the article are calibrated using software OxCal v 4.3.2 (Bronk Ramsey 2017) and the IntCal13 atmospheric curve

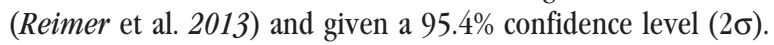


nological marker. But his criteria for pottery grouping are often incomprehensible, since clear definitions of types were substituted for description of a few of the brightest vessels or generalized descriptions of some ceramic group from the monument that was becoming eponymous. The earliest Ziankivtsi non-pottery phase is associating with the late Mesolithic now. Two other phases, the Sokiltsi and Khmelnyk, looked somewhat unconvincing even in Danylenko opinion (Danilenko 1969.150-151). Soon after they were disproved by the majority of specialists (e.g., Tringham 1971.97, 100-101; Telegin 1977.89). Thus, somewhat schematically, the periodization scheme proposed by Danylenko consists of a sequence of four variant of pottery.

The Skybyntsi type pottery was correlated with the earliest BDC period. Typically it is made in a truncated egg-shape and decorated by parallel incised lines forming wavy bundles and meander patterns filled with incised crosshatching or stroke impressions. According to Danylenko, their common features are the use of silt paste containing organic fibres and coarse shell fragments, as well as their pointed bottoms. These were considered as evidence of their eastern, Azov-Caspian steppe origin in a time before Balkan influences had reached the region (Danilenko 1969.150-151).

The next period was characterized by pottery of the Pechera type. These vessels are made of ceramic paste of the same composition but have a flat base. Their relatively late age was determined by similarity to the Cris pottery from Romania, due to their globular and elongated globular shapes, surface treatments, decoration with pinches, fingernail impressions and various plastic applications as a rule combined with incised zigzag patterns. Their synchronous development was supported by discovering at sites of Pechera I, Sokiltsi VI, and Hlynske I, where a number of burnished Cris-like vessels made of finestructure paste has been documented (Danilenko 1969.152-153), which are now interpreted as real Criş 'imports' (e.g., Wechler 2001.274, 275, 278).

According to Danylenko, the Pechera pottery was replaced by the Samchyntsi type vessels. They are characterized by a pointed or round bottom, the presence of gravel and stones in the ceramic paste, decoration by imprints of various notched and comb-like stamps, as well as the lines scratched by them. He thought that the origin of the Samchyntsi tradition was linked to the Eastern European forest zone. Its time of appearance was correlated with the 'music- note' phase of the Linear-Band Pottery Culture (henceforth, LBPC), because of the finding of numerous Samchyntsi vessels and two LBPC bowls at one depth in the Bazkiv Ostriv site (Danilenko 1969.66, 156, 207).

The Savran type pottery, correlated with the latest period of the BDC, was indistinctly defined by $\mathrm{Da}$ nylenko as characterised by flat and pointed bottoms as well as "almost unlimited domination of an impressed linear decoration" (Danilenko 1969. 154). When describing finds of the Savran period, Danylenko did not mention the materials of other cultures among them. Thus, he justified their late age only by stratigraphic observations at the monuments of Bazkiv Ostiv, Mytkiv Ostriv, Sokiltsi II and Ziankivtsi II.

Later, six other periodization schemes for the whole culture or its local variants were proposed by Ruth Tringham (1971.97), Dmytro Telehin (Telegin 1977. 90), Klaus-Peter Wechler (2001.30-31, 52-54), Markevich (1974.127-143), Nadiia Kotova (2003.3032), Tovkailo (Tovkaylo 2014.235-239), Ihor Sapozhnikov and Halina Sapozhnikova (Sapozhnikov, Sapozhnikova 2005.92). However, they consisted mainly of the renaming, correction and mechanical merging of Danylenko's phases and periods (Tab. 2). But they did not touch on the basic sequence of his scheme, which was agreed by all the researchers. In a maximally general view, this erupted into the common belief that the dominant type of admixture in clay divides the BDC sites in the Buh area into two groups: the earlier with numerous vessels tempered by coarse shell, and the later with isolated cases of its use or without such pottery. Ultimately it was reflected in the simple two-part periodization (Kotova 2003.30-32). The difference in the researchers' views is the synchronization of the neighbouring cultures with BDC pottery types, as well as indirect absolute dating of the lasts.

Indirect absolute dating of the pottery types

The analysis of publications allows us to distinguish two approaches to indirect absolute dating of the BDC pottery types. They are different by the source of the radiocarbon dates used.

The external approach leans on the pottery typology and the finds of mutually 'imported' vessels. On the basis of the latter, radiocarbon dates of corresponding neighbouring cultures are projected to the BDC sites. This method arose long ago, and was the only one possible before the beginning of the mass 
radiocarbon dating of BDC. Its followers synchronize the Skybyntsi and Pechera pottery with the Cris materials from Moldovian and Romanian sites, dated to the range of the $59^{\text {th }}-54^{\text {th }}$ centuries BC. Vessels of the Samchyntsi type are synchronized with LBPC sites, dated to range of $54^{\text {th }}-50^{\text {th }}$ centuries $\mathrm{BC}$, and the Savran type initially with LBPC, and then with early Trypillya settlements, which start appearing $c$. the $48^{\text {th }}$ century BC in Ukraine. The origin of the culture is linked by supporters with the Balkans-Danube region (Tovkaylo 2005.44-49; 2014.235-239; Gaskevych 2007; Zaliznyak et al. 2013.249-250).

The internal approach leans, first of all, on the mass series of the 'new' radiocarbon dates measured on bones and projected onto certain groups of BDC pottery. But the basis of this approach is the same traditional conception about the sequence of the pottery types. Thus, its followers project the high dates of the $7^{\text {th }}$ millennium BC onto the Skybyntsi and Pechera vessels, and low dates in the range the 59th$53^{\text {th }}$ centuries BC onto the Samchyntsi and Savran ware. Consequently, the first two types are considered by them as preceding the Cris Culture, and the second two as synchronous with the Cris and partially LBPC (Kotova 2003.30, 50). In fact, these researchers have just shifted the whole traditional sequence of pottery types several centuries deeper. Logically, they and their adherents support the idea of the non-Danube origin of the culture, since the Neolithic dated to $6400 \mathrm{BC}$ is not found to the west (e.g., Reingruber 2017.93-94).

Followers of the first approach criticized the second one because of the well-known presence of typical Pechera pottery at Criş settlements of Moldova, dated to the middle of the $6^{\text {th }}$ millennium BC (Dergachev, Larina 2015.176-180), as well as discovering the typical LBPC pottery together with the Samchyntsi and Savran vessels on the BDC sites of Bazkiv Ostriv (Danilenko 1969.66), Shchurivtsi-Porih (Gaskevych 2008b.170), Dobrianka-3 (Zaliznyak et al. 2013.234), Gard (Tovkaylo 2014.201-202), Tătărăuca Nouă XV (Larina 2006), and vice-versa, the BDC pottery on the LBPC settlements of Maynova Balka (Larina et al. 1999.27), Rusestii Noi I (Markevich 1973.25), and Gura Camencii VI (Larina 1999. 104). But these researchers could not explain the 'new' Kyiv dates pointing to the beginning of the $\mathrm{BDC}$ being around the middle of the $7^{\text {th }}$ millennium BC, before the start of Neolithisation in the DanubePrut region; and its ending before the beginning of the Precucuteni-Trypillya Culture. Therefore, they questioned the validity of the 'new' Kyiv dates as such. Afterwards, this distrust extended to all dates from the Kyiv laboratory, although many of them do not contradict the measurements of other laboratories and synchronization data. The situation has come to a standstill, and one way out could be an attempt to re-view the BDC periodization, as well as the direct dating of vessels of various types.

\section{Attempts at revising the traditional views}

In the early 2000s, one of this article's authors was a follower of the external approach and one of the steady critics of the 'new' Kyiv dates (Gaskevych 2007). But his excavation, collating of the old collections, a study of archaeological context and the typological analysis of finds have enabled him to try transforming some of the traditional views concerning the BDC to eliminate the inconsistency in its dating.

First, all of the available finds of vessel bottoms from the Southern Buh monuments were analysed (Gaskevych 2008a). It was established that in fact among the pottery attributed by Danylenko to the Skybyntsi type only one pot from the Bazkiv Ostriv site has a pointed bottom. It is made of paste without shells and adorned with meander decoration. It has reaffirmed the unlikely nature of chronological opposition of the Skybyntsi and flat-bottomed Pechera types (Telegin 1977.90; Wechler 2001.52) that allowed considering of all the vessels with coarse shell inclusions as synchronous with the Criş settlements in Moldova. On the contrary, all the Samchyntsi type vessels turned out to have pointed and round bottoms. Since analogies to these are absent in the Danube Neolithic, a question about distinguishing a specific tradition (or even culture) with a genesis different from the BDC, and an area wider than its own, was raised (Gaskevych 2008a; 2008b; 2010; 2011).

Second, re-excavation of two 'classical' sites on both the Buh (Pechera I) and the Dnister (Tsekynivka) was carried out (Czerniak et al. 2013). The results and critical consideration of the archaeological context from old excavations testified to the poor state of cultural stratigraphy on most BDC monuments. No reliable closed contexts such as pits or semi-subterranean houses have been documented in the Southern Buh area. Vessels of different types are spaced apart planigraphically, which does not allow us to assert a sequence of their getting in sediments at some monuments, which were published as 'wellstratified' before (Gaskevych, Kiosak 2011.202; Gaskevych 2017a.88-90). But in most cases, they lay 
mixed (Gaskevych 2013.11-13). Consequently, the bones used for radiocarbon dating were frequently found next to the pottery of different types (e.g., Gaskevych 2017c.200-201).

The observation of real cultural stratigraphy has allowed us to assume that the high measurements on bones do not date the Cris-like Pechera vessels, but the round-bottomed Samchyntsi ones decorated with a comb. Since the presence of domesticates in the BDC was generally not questioned a decade ago, analogies were looked for in the southern Mediterranean. There, pottery similar to the Samchyntsi and dated before the $6^{\text {th }}$ millennium $\mathrm{BC}$ is in the Middle East (Balossy Restelly 2006) and Northern Africa (Jesse 2010). Therefore, a hypothesis about the marine expansion of the earliest Impresso traditions to the North-Pontic region in the period preceding Balkanization was put forward. This was facilitated by the discovery of pottery with Cardium decoration and an admixture of the valves of brackish water ostracods Ciprideis torosa littoralis (Brady 1864) in the collections of some BDC monuments (Gaskevych 2010; 2011; Tovkaylo 2012). Consequently, it was assumed that the pointed-and round-bottomed comb decorated vessels were one of the first types of pottery in a significant part of the territory of Ukraine and became one of the main background pottery types there. In the contact zone with the western agricultural population, the traditions of Cris, Alföld, Vinča, Dudesti cultures influenced it at different times. They determined the appearance of various local decoration styles (but not phases) such as the Skybyntsi, Pechera, Savran, and some other nameless ones.

Afterward, the almost complete absence of Southern Buh forest-steppe Mesolithic monuments has attracted attention. The only exception is the late Mesolithic level in the Ziankivtsi II site (Danilenko 1969. 90). Its 'new' radiocarbon date points to the same range as the most ancient Kyiv dates of the BDC settlements Sokiltsi II, Bazkiv Ostriv, Mytkiv Ostriv, and Pechera I. Therefore, it was assumed that late Mesolithic finds could form palimpsests with slightly younger finds of the BDC on those and some other sites (Gaskevych 2012; 2014.10). A series of characteristic flint tools of the Late Mesolithic Kukrek Culture, which were discovered there earlier (Gaskevych 2005; 2012), support this conclusion. It logically explains the early Kyiv measurements of the BDC without a far-fetched hypothesis about the very early marine diffusion of Impresso pottery. So, the latter could start in the North-Pontic area synchro- nously with the Northern and Western Mediterranean in the $6^{\text {th }}$ millennium $\mathrm{BC}$.

Thus, the state of the majority of sources allows the creation of various explanatory models correlating different types of finds with any dates on bones and demolishing traditional views concerning the origin and development of the BDC. Under these circumstances, almost the only way one can avoid speculation and check the existing chronology and periodization as well as the suggested hypotheses is direct radiocarbon dating on pottery.

\section{Direct radiocarbon dating on pottery}

Today, the 16 conventional dates on organic inclusions in 15 pottery samples from four BDC monuments (Dobrianka-1, Dobrianka-3, Gard, Hirzhove), and two AMS dates on carbonized crust on the surface of one vessel from the Tătărăuca Nouă XV site, have been published. Of these, the last two were measured at the Kiel and 16 other at the Kyiv laboratory. Unfortunately, a detailed description of the decoration and ceramic paste composition, as well as a well-reasoned attribution to some type of pottery, is not given for all samples. The too large standard errors $( \pm 140-230$ years) of some measurements seriously diminish their utility. But even these dates allow us to question the established views on the relative and, partially, absolute chronology of certain pottery types, and the BDC as a whole. In this sense the dates for the sites of Gard, Dobrianka-1 and Hirzhove are very significant.

The settlement and burial ground of Gard, located in the steppe Southern Buh region, were excavated by Tovkaylo over the last 12 years. He identified two BDC horizons, separated by a 'relatively sterile' layer on some part of the monument's area. The researcher believes that the lower horizon is characterized by the finds of 'early Neolithic' pottery of the Pechera type, which he typologically synchronizes to phases III and IV of the Criş Culture, according to its subdivision by Gheorghe Lazarovici (1984). But an LBPC vessel with the 'music-note' decoration was also found there. The upper horizon he characterizes by the finds of 'Late Neolithic' pottery of the Savran type, as well as of the early Trypillia pottery of the Sabatynivka II type (Tovkaylo 2014). Two dates of the second to third quarter of the $6^{\text {th }}$ millennium $\mathrm{BC}$ were measured on the samples of the 'early' BDC pottery, one of which (Ki-14789) is made of paste with coarse shell fragments. The dates on three samples of the 'late Neolithic' pottery pointed to the same time range (Tab. 1). The location of the 'early' 
sample Ki-14790 and the 'late' one Ki-14791 in the same square and depth (Tovkaylo 2010.Tab. 2) also indirectly confirms at least partial synchronization of the measured vessels of the Pechera and Savran types.

The site of Dobrianka-1, located in the Sinyuha River basin between the BDC and Kyiv-Cherkasy culture areas, was investigated by Zalizniak's expedition in 2001-2006. A representative flint complex of the Mesolithic Kukrek culture and fragments of no less than 10 vessels with some characteristics of pottery from steppe BDC sites were found there. The stratigraphic position of the Sub-Neolithic materials is uncertain (Zaliznyak et al. 2013.195-214). The fragments of two vessels - one with two-pronged stamp impressions and other with a pointed bottom and gridlines decoration - were measured for the

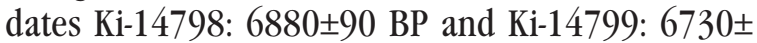
90 BP, respectively (Manko 2013.216; 2016.271, 278). The age of the first sample, attributed to the Samchyntsi type (Zaliznyak et al. 2013.214, Fig. 14.6), turns out to be older than the Pechera and Savran type pottery from the Gard site, and the second one coincides with them in time.

The settlement of Hirzhove is located on the Kuchurgan River (left tributary of the Dnister River) in the steppe zone. It was excavated by Pavel Boriskovskiy and Volodymyr Stanko in 1961-1963. They represented the site as a classic monument of the Late Mesolithic Hrebenyky culture. But the 'Neolithic horizon' with characteristic geometric microlithics and some fragments of BDC pottery with comb impressions, which were referred by Danylenko to the Samchyntsi type, is mentioned in publications, too (Stanko 1966; 1967). Two 'new' Kyiv dates that fall into the last quarter of the $7^{\text {th }}$ millennium $\mathrm{BC}$ were measured on the same potsherd in 2004 (Manko 2006.19). They were used as one of the rationales for the early appearance of the Samchyntsi type pottery in the region (Gaskevych 2011.282).

Re-publishing of the site by Vladyslav Petrenko proved the finds of all periods lay mixed at a depth up to $0.5 \mathrm{~m}$ in the soil layer disturbed by deep ploughing. One fragment of the LBPC vessel and more than 100 potsherds of BDC pottery were attributed by Petrenko in the collection. Description and drawing of the measured sample, published for the first time, has shown that the potsherd is adorned with a double line and a parallel row of simple impressions (Petrenko 2012.235-236, Fig. 4.1). This decoration is not typical for the Samchyntsi style, and this rather shattered the idea about the antecedence of pottery with comb impressions in the Northern Black Sea area.

Thus, if we consider the direct dating on only moreless well-published pottery samples, the earliest is measuring on the vessel of an unattributed type from Hirzhove. Somewhat younger are the Samchyntsi vessels from Dobrianka-1. Vessels with some Criş characteristics and coarse shell fragments in the paste from Gard are, as expected, synchronous with the Cris sites of Moldova and dated back to the middle of the $6^{\text {th }}$ millennium BC. The Savran pottery from Gard also points to this time.

The above dates are contrary to all periodization schemes of the BDC created over a half-century. Therefore they have been met with disapproval and been ignored by most followers of both external and internal approaches. The first justify this by scepticism about the Kyiv laboratory, where the dates were measured (Zaliznyak et al. 2013.249; Tovkaylo 2014), and the second by the unreliability of the measured material (Kotova 2015.13). Doubts about the reliability of measurements in the Kyiv laboratory can easily be verified by dating in other laboratories, as is done later in this article. But the disadvantages of direct dating on pottery are well-known and it cannot be overcome. Therefore, possible distortions of the real age of the samples should be taken into account.

\section{Sample description}

Eleven samples - nine fragments of pottery with organic inclusions in the paste and two charred residues on the pottery surface - were selected from collections of three sites.

\section{Shumyliv-Cherniatka}

The monument is situated at $48^{\circ} 29^{\prime} 17.69^{\prime \prime} \mathrm{N}, 29^{\circ} 40^{\prime}$ 33.54 " $\mathrm{E}$ on the high part of the floodplain on the left bank of the Southern Buh River between the villages of Shumyliv and Cherniatka (both - Bershad district, Vinnytsia region) near large rapids. It was investigated by Danylenko in 1960. The surface was heavily destroyed by the construction of a hydroelectric power station dam. According to published data, an area of more than $300 \mathrm{~m}^{2}$ has been uncovered. A few clusters of the Sub-Neolithic and early Trypillia materials lay at a depth of $0.5-0.8 \mathrm{~m}$ in a layer of "dense grey-green loam" treated by the researcher as "ancient meadow-type soil" (Danilenko 1969.121-125). 
According to our preliminary calculations, the collection stored in the Institute of Archaeology of NAS of Ukraine now includes 450 potsherds of roughly dozen Sub-Neolithic pots and 314 fragments of no less than 19 early Trypillian vessels, 303 knapped flints, two not flint pebbles, and two pieces of bones. Where the other 1397 intact and broken animals' bones and seven processed bones mentioned in the field documentation are stored is unknown. Perhaps they are lost.

Danylenko attributed the site to the Savran phase (Danilenko 1969.121).

This monument has been chosen for sampling because it allows us to check widespread views about the partial synchronism of the late BDC and early Trypillia culture (e.g., Tringham 1971.167-168; Tovkaylo 2005.39, 40). Second, a fragment of BDC vessel with an extremely rare carbonized crust has been found in the collection.

Two samples taken from the site collection have been measured.

\section{Shum $1 t$}

The sample is a fragment of a wall (field inventory No. 183 , square $26 \mathrm{G}$, without depth mark) of the vessel, which is represented by 128 fragments stored in the collection. The vessel was probably a pot with a cylindrical upper body of about $30 \mathrm{~cm}$ diameter, and inverted conical bottom part. The rim is slightly everted. The lip is rounded, straight. The bottom is
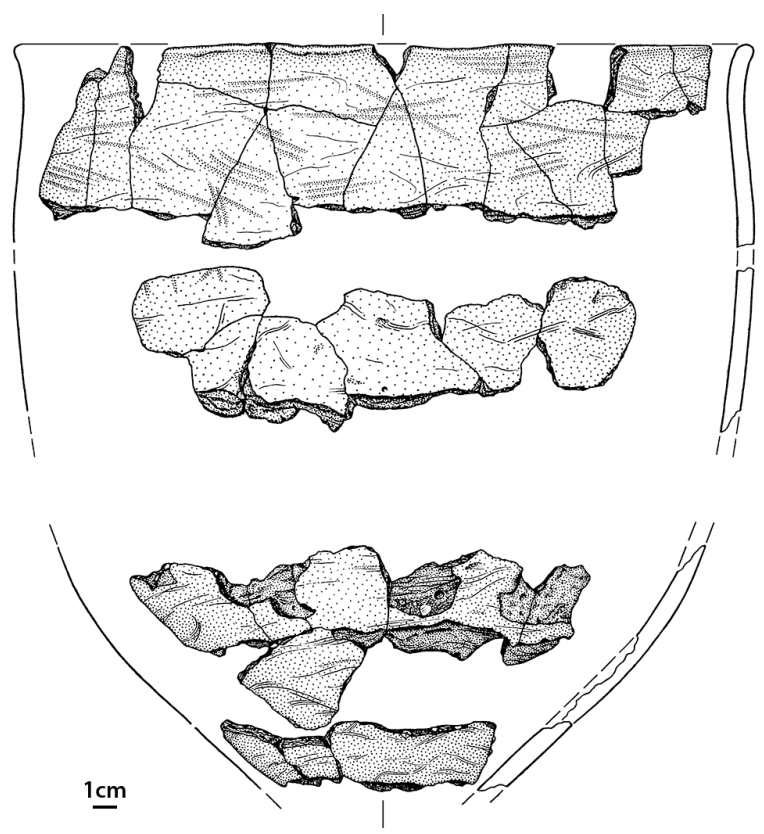

Fig. 2. Chumyliv-Cherniatka. Vessel, dated by samples Shum-1c and Shum-1t. missing. The wall thickness is $0.6-0.8 \mathrm{~cm}$. The pottery paste contains a lot of sharp-cornered gravel (up to $0.6 \mathrm{~cm}$ ), sand and organic fibres as well as a little crushed shell (up to $0.6 \mathrm{~cm}$ ). The outer surface is light reddish brown, pale red, grey, very dark grey. The inner one is very dark grey, pinkish grey, light reddish brown, grey. The colour of the fractures is various, irregular. Both faces of the rim are roughly smoothed with a notched tool that left characteristic traces in many places. The body is smoothed better. No decoration is observed on the preserved part of the vessel (Fig. 2).

\section{Shum 1c}

The thin coat of charred organic residue in the form of two dark brown spots, each less $1 \mathrm{~cm}^{2}$ large, was scraped off the inner surface of the potsherd, which is the sample of Shum 1 t.

\section{Hlynske I}

The site situated roughly at $48^{\circ} 44^{\prime} 27.19^{\prime \prime} \mathrm{N}, 29^{\circ} 5^{\prime}$ $14.55^{\prime \prime} \mathrm{E}$ is now flooded by waters of the Ladyzhin hydropower station reservoir. Neolithic finds were collected by Pavlo Khavliuk and Danylenko on the surface of a more than $100 \mathrm{~m}$ part of the right lower (about 3m high) terrace of the Buh River, to the south of the Hlynske village (Nemyriv district, Vinnytsia region) in 1955 and 1957. They cleaned section of steep terrace edge $35 \mathrm{~m}$ in length in 1957. That year, two small trenches (Complex 1 on $22 \mathrm{~m}^{2}$ and Complex 2 on $6 \mathrm{~m}^{2}$ ) were investigated at opposite ends of the cleaned area.

All the sources about the monument are Khavliuk and Danylenko's field documentation and a very incomplete description in Danylenko's monograph (1969. 105-107). The collection is stored in the Institute of Archaeology of NAS of Ukraine. Its SubNeolithic part consists of 160 fragments of 16 vessels, 82 flint artefacts, one bone tool, and six animal bones. A comparison of the finds and field records shows the presence of almost all the pottery and flints, but most of the bones are missing.

The pottery is subdivided into three types: the Samchyntsi, Pechera, and Criş-like. The location of vessel fragments discovered on the surface was described very roughly, and the stratigraphic sequence of different type pottery from trenches has not been recorded. Thus, both Danylenko's statement that the Hlynske I is a stratified settlement with the Pechera and Samchyntsi phases of occupation (Danilenko 1969. $107)$, and the note about the site 'bottom layer' repeating by Kotova (2002.22; 2003.30; 2015.40, 41, 
102) are in fact unfounded. However, the absence of the Samchyntsi type pottery in the relatively wellpreserved Complex 1, uncovered in a layer of yellow loam at the of depth $3.1 \mathrm{~m}$, was strictly ascertained (Danilenko 1969.106; Gaskevych 2017a.107).

Complex 1 in the monument of Hlynske I has been chosen for sampling because two vessels very similar to Criş-Körös fine pottery or even imported from the area of that culture were found there. Their shards lay around stone fireplaces close to the fragments of the Skybyntsi and Pechera type vessels (Fig. 3). This allows for checking the possible synchronism of the mentioned types of pottery.

Two sampled potsherds from the site have been measured.

\section{Hlyn-2t}

The sample is a fragment of a wall (collection inventory No. 93, field inventory No. 9, Complex 1, square 2-3/a, without depth mark) of vessel 16 . There are five debris of this vessel in the collection. All were found in a compact cluster in marginal squares in the Complex 1 and the outcrop of a fluvial terrace edge. The largest fragment lay on the stone fireplace in square $1 / \mathrm{a}$ (Fig. 3). The vessel can be reconstructed as a biconical bowl with a pronounced body corner. The maximum diameter is $15 \mathrm{~cm}$; the height of the extant part is $10.5 \mathrm{~cm}$. The rim is vertical, slightly thinned; the lip is rounded, straight. There are remnants of a broken pedestal foot base on the bottom surface. As far back as Neolithic times fractures of the pedestal were rasped off to make the vessel steady. The wall thickness is $0.5-0.9 \mathrm{~cm}$. The pottery

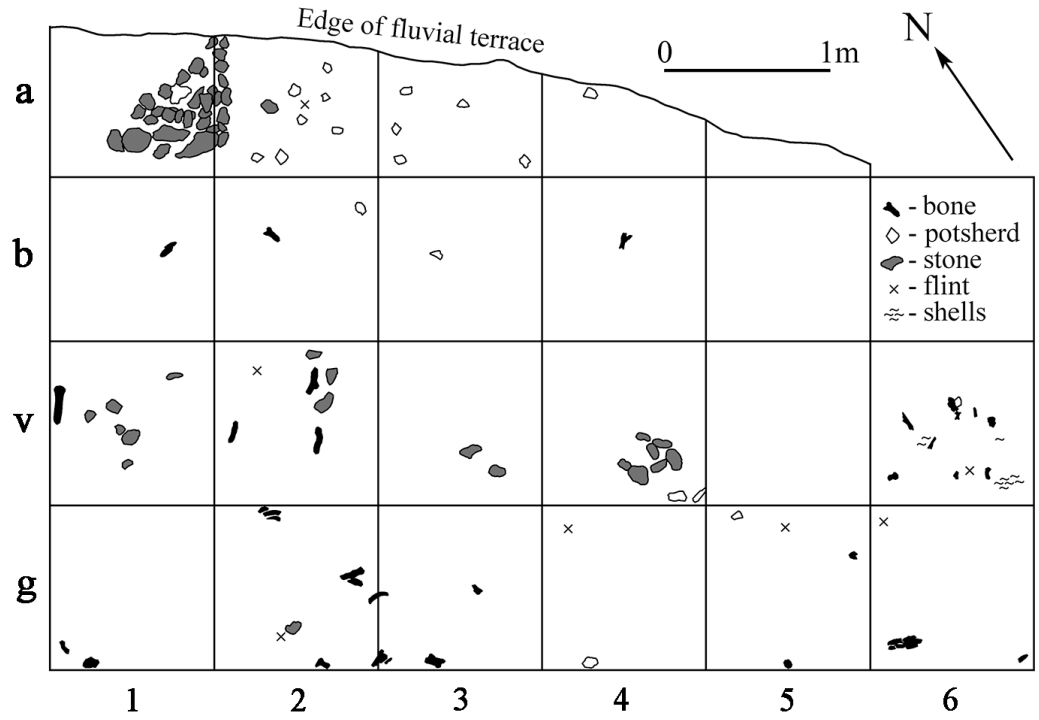

Fig. 3. Hlynske I. Plan of the Complex 1. According to Danylenko's field drawing. paste is soapy and flaky. It consists of clay, containing a small amount of organic matter and very fine slightly micaceous sand. The external surface was smoothed, covered in slip and burnished. But now it is eroded off in many places. Its colour is dark grey, brown, very dark greyish brown, black. The inner surface is smooth; very dark grey, black. The fractures are dark grey. Decoration - hardly observable knobs on the body corner (Fig. 4). In the late 1950s the vessel was reconstructed in an artisanal way. In this process, some part of the surface was washed off and treated with abrasive.

\section{$H l y n-3 t$}

The sample is a small decorated fragment of a wall (collection inventory No. 51, field inventory No. 8, Complex 1 , square $4 / \mathrm{b}$, without depth mark) of vessel 7. In the collection, this vessel is represented by 21 fragments. They were found within the whole area of Complex 1 as well as in the outcrop and cleaning of the terrace edge. Probably, the vessel had a cylindrical body with a maximum diameter of about $20 \mathrm{~cm}$. The rim is outwardly thinned and slightly inverted. The lip is rounded, straight. The bottom is missing. The wall thickness is $0.8-1.2 \mathrm{~cm}$. The pottery paste is well-kneaded. It contains small amounts of coarse fragments of shells (up to $1.0 \mathrm{~cm}$ ) and vegetable fibres. Both surfaces are smooth, with remains of burnishing preserved in some places. The colour is light reddish brown and pinkish grey with greyish brown spots. Fractures are black. The vessel is decorated with zones, contoured by curved both superficial impressed and deeply cut lines $0.1-0.2 \mathrm{~cm}$ thick. The row of densely arranged pits imprinted by a tubular stamp of $0.4 \mathrm{~cm}$ diameter is along the lines from the outside of zones. The surface within these zones is filled with a grid pattern drawn with diagonal lines of the previously mentioned nature (Fig. 5). The figure, which these zones form, cannot be recognized. Perhaps, it is irregular like on a wellknown pot from the Mytkiv Ostriv site (Danilenko 1969.Fig. 33, 34.2; Wechler 2001.Taf. 5.5).

\section{Bazkiv Ostriv}

The monument situated roughly at $48^{\circ} 33^{\prime} 06.72^{\prime \prime} \mathrm{N}, 29^{\circ} 21^{\prime} 30.27^{\prime \prime} \mathrm{E}$ is now submerged by waters of the Hlybochek hydropower plant reservoir. It was investigated by Danylenko on the same name is- 
land to $3.5 \mathrm{~m}$ high in the middle of a rapid part of the Southern Buh River near the village of Skybyntsi (Trostianets district, Vinnytsia region) in 1959. The site description, published by Danylenko, is very brief. The pottery of the Skybyntsi, Samchyntsi and Savran types, each associated with a distinct layer, were recorded by him there (Danilenko 1969.6269). Later Kotova considered the site as the best in the BDC owing to the representativeness of its collection and accuracy of its stratigraphy, although she distinguished only two cultural layers there (Kotova 2003.26-29).

All available sources regarding the site have been re-analysed recently (Gaskevych 2017c). An area of over $300 \mathrm{~m}^{2}$ was investigated there during a mere 28 workdays. The Sub-Neolithic materials were found in a layer of sediment described by Danylenko as 'yellow-grey loess-silty loam'. It was of different thickness and occurred at varying depths in different parts of the monument. The excavated area of a total of $247 \mathrm{~m}^{2}$ was drawn on the plans including marks of 3381 finds - 1353 fragments of pottery, 487 flint artefacts, 1509 bones and bone tools, 32 shaped and not-shaped stones of not-flint rock. But today, the settlement collection stored in the Institute of Archaeology of NAS of Ukraine consists of only 1403 labelled items including 701 fragments of 90 vessels, 665 flint and three not-flint stone arte-

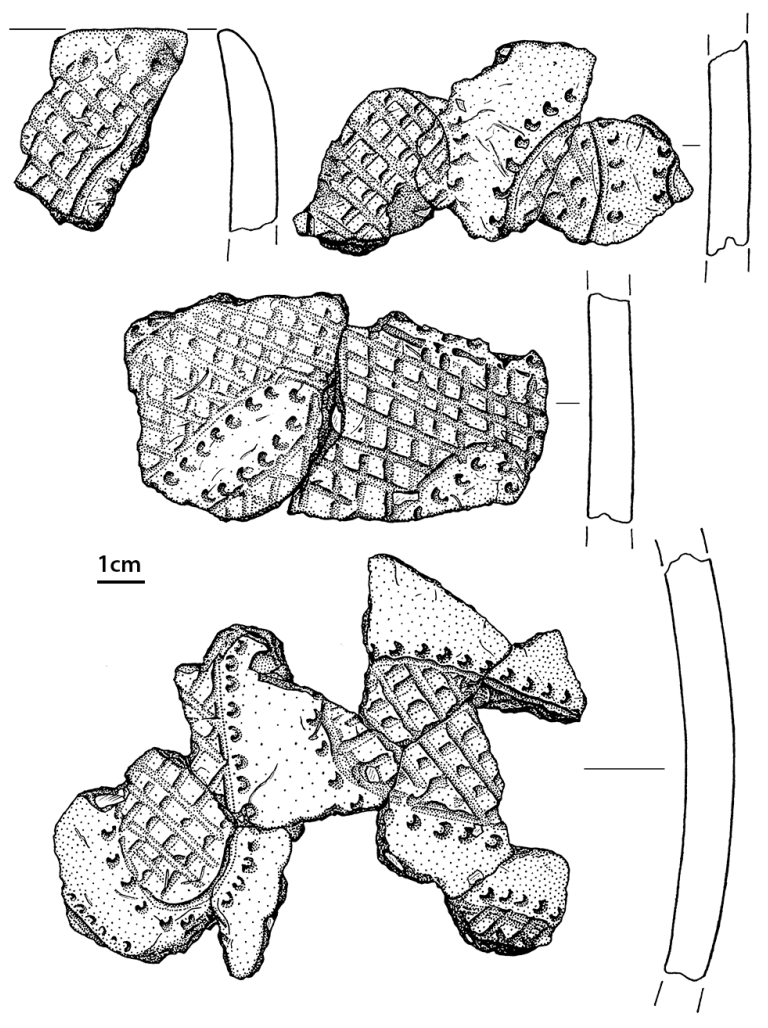

Fig. 5. Hlynske I. Vessel 7 dated by sample Hlyn-3t.

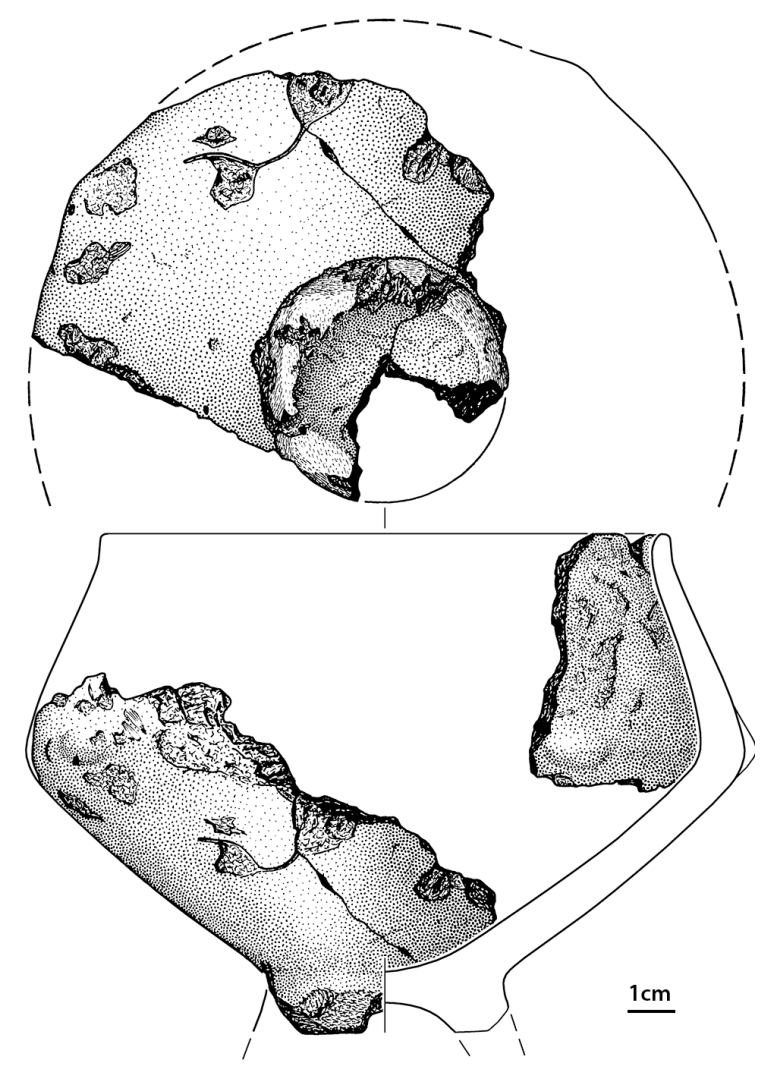

Fig. 4. Hlynske I. Vessel 16 dated by sample Hlyn-2t.

facts, 34 animal bones, bone and antler tools. Another 375 intact and broken bones of animals and fish are stored in the Palaeontology Department of the National Museum of Natural History of NAS of Ukraine. However, the lack of field labels reduces their value for analysis. The rest of the materials are considered lost.

A comparison of nine stratigraphic sections of the trenches allows two important conclusions. The first - a slight declivity of the ancient surface is recorded on the settlement. The second - because of the absence of precise topographic instruments all depths were measured from the datum line, drawn on different walls of the trenches at varied absolute depths. So, nominally identical depths of finds from different parts of the site may in fact (along the absolute calculations) also be different. Thus, a vertical sequence of finds from various depths measured from only the same drawn datum line is correct.

Because of the above, the site stratigraphy has been analysed from the number of finds marked on the field drawings, for each of nine zones numbered from II to $\mathrm{X}$ and representing stages of increasing the excavation area (Fig. 6). A small area of each zone allows disregarding the natural declivity of the ancient surface, and the use of the same datum lines 
allows comparing the depths of finds more or less reliably. The number of finds from different depths shows a possible presence of three horizons of concentration increase - two with pottery (Sub-Neolithic) and one non-pottery (Mesolithic). No 'sterile' layers between them have been recorded.

The different estimated ages of the two possible ceramic layers in Bazkiv Ostriv suppose the typological difference of their pottery. The depth of only large available fragments has been taken as the criterion for linking vessels to excavation levels. This approach is based on two postulates: the position of larger potsherds in sediments is more stable; impacts of the forces which move fragments in sediments break them at the same time (Tsetlin 1991. 27). So, 93 potsherds larger $20 \mathrm{~cm}^{2}$ have been analysed. They represent $31 \mathrm{BDC}, 1 \mathrm{LBPC}$, and 4 Trypillian vessels.

The analysis results have shown the arising of two recognised ceramic horizons at some zones owing to the way of recording the depth of the finds. In other zones, differences in the pottery types from both horizons are absent or not detected due to the loss of most shards. Thus, the presence of evident cultural layers mentioned by Danylenko and Kotova has not been confirmed. Instead, considerable mixing of materials, attributed by them to different periods of the culture, has been established. The recorded vertical sequence of the compact clusters of several vessel shards contradicts traditional views concerning a sequence of the BDC pottery types. It is in concordance with the organic combining of technological and decorative characteristics, traditionally attributed to the different periods, noted for some vessels (Gaskevych 2017c.199).

The site of Bazkiv Ostriv has been chosen for sampling because fragments of two LBPC vessels were found there. It allows checking Danylenko's views about the synchronism of the 'music-note' wares and Samchyntsi pottery (Danilenko 1969.66, 154). Second, a series of seven radiocarbon dates on animal bones was measured for the site at Kyiv laboratory in 1998 and 2000 (Telegin et al. 2000; Kotova 2002). It allows comparing the results obtained on different materials at different laboratories.

Seven samples taken from the site collection have been measured.

\section{Bazk-4t}

The sample is a decorated fragment of a wall (without inventory No., square B' $/ 5$, depth $-1.03 \mathrm{~m}$ ) of vessel 23 . There are only six fragments of this vessel in the collection now. Half of them were found in square $\mathrm{B}^{\prime} / 5$ in zone VI at a depth of $1.03 \mathrm{~m}$ (Figs. $6,7)$. But a compact cluster of 15 potshards is marked in this place and depth on the field plan. Probably the vessel was a semisphere shape. The rim of about $18 \mathrm{~cm}$ diameter is slightly tapered. The lip is rounded, and, in some places, flattened. The bottom part is missing. The wall thickness is $0.7-0.9 \mathrm{~cm}$. The pottery paste contains an admixture of organic fibres, waterworn fine sand and a large amount of shell fragments (up to $0.8 \mathrm{~cm}$ ). The outer surface is well smoothed; dark reddish grey, greyish brown

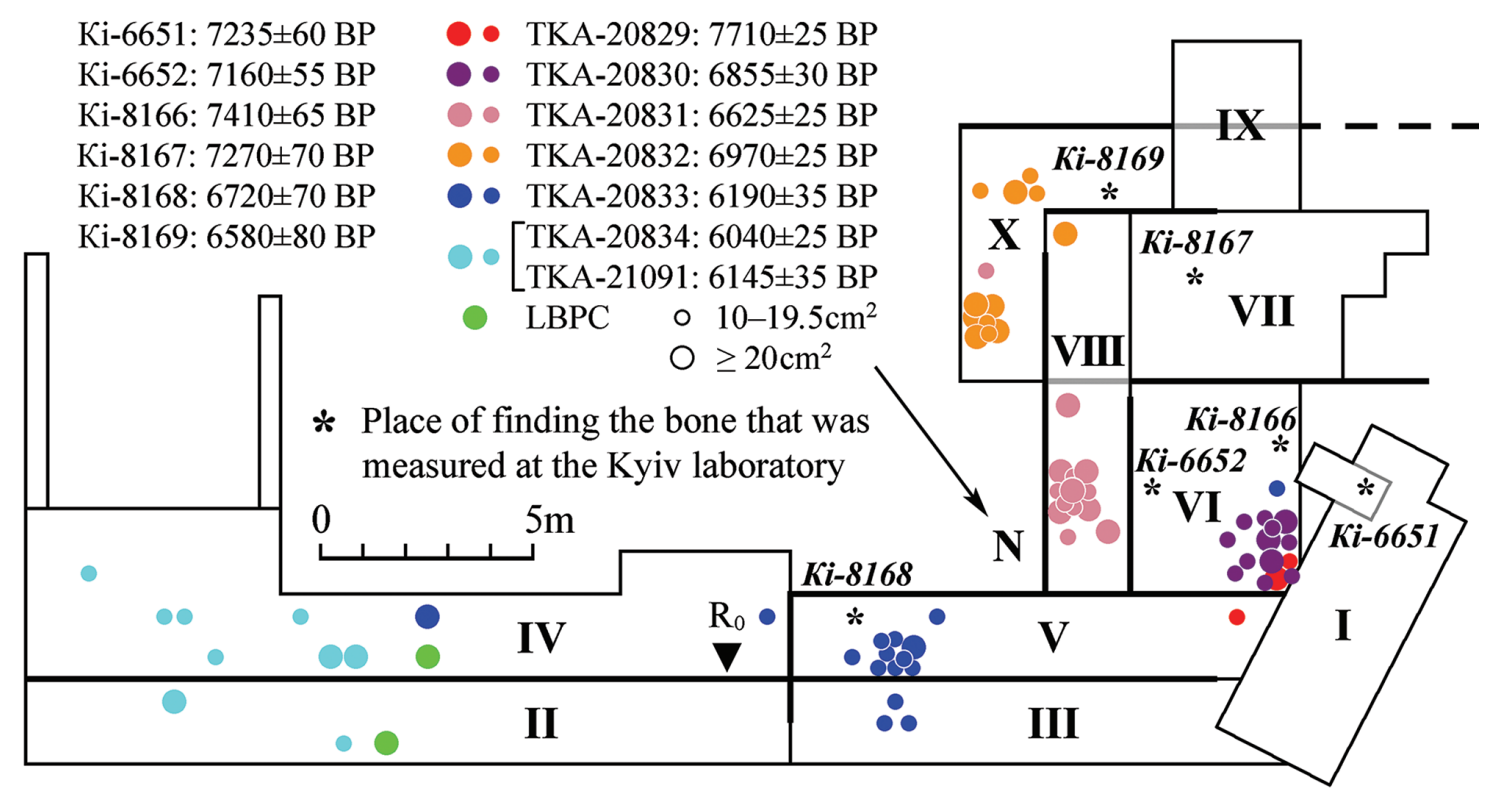

Fig. 6. Bazkiv Ostriv. Excavations scheme with margins of the zones and samples location. 
and dark brown. The inner surface is well smoothed; brown, greyish brown, very dark greyish brown, pinkish grey. Fractures are black. Decoration - a solid zone filled with pinches (twin fingernail impressions) covering the whole body except the edge and the bottom part (Fig. 8).

\section{$B a z k-5 t$}

The sample is a fragment of a wall (field inventory No. 1 , square B' $/ 6$, depth $0.9 \mathrm{~m}$ ) of vessel 1 . In the collection, the vessel is represented by 31 fragments found within zones I, V, VI, VII, with 16 laying in a sufficiently compact cluster in squares $A^{\prime}-B^{\prime} / 5-7$ in zone VI at a depth of $0.9-0.99 \mathrm{~m}$ (Figs. 6,7 ). The vessel is reconstructed as a pot with a slightly everted rim of $22 \mathrm{~cm}$ diameter and hemispherical low part with a maximum diameter of $22 \mathrm{~cm}$ too. The rim is thinned. The lip is rounded, straight. The bottom is missing. The wall thickness varies from $0.6 \mathrm{~cm}$ to $1.0 \mathrm{~cm}$. The pottery paste contains an abundant admixture of thin organic fibres, some quantity of the waterworn pebbles and sand as well as grog in the form of small rounded clots of unburnt white clay. The outer surface is well smoothed; very dark greyish brown, greyish brown, brown, reddish brown. The inner one is black, very dark grey, very dark greyish brown. The fractures are black. Decoration two horizontal belts consisting of parallel rows of notched stamp impressions, separated from one another by a horizontal zigzag pattern drawn using the same comb stamp (Fig. 9). The closest analogy to this composition is a decoration of the best Samchyntsi type pot - vessel 3 from the eponymous Samchyntsi I site (Gaskevych 2010.217, Fig. 2; 2011.Fig. 3.3).

\section{Bazk-6t}

The sample is a decorated fragment of a wall (square $\check{S} / 6$, without inventory No. and a depth mark) of vessel 22. There are 20 fragments of this vessel in the collection. Most of them were found in a compact cluster in square $\breve{S} / 7$ in zone VIII at a depth of $0.8-0.89 \mathrm{~m}$ (Figs. 6,7$)$. The vessel can be reconstructed as a pot of truncated ovaloid (egg-like) shape. The maximum diameter is $19 \mathrm{~cm}$; the height is at least $21 \mathrm{~cm}$. The slightly thinned rim is inverted. The lip is flat, straight. The bottom is missing. The wall thickness is $0.6-0.9 \mathrm{~cm}$. The pottery paste contains an admixture of thin organic fibres, a small amount of sharp-cornered gravel and shell fragments (up to $0.7 \mathrm{~cm}$ ). The outer surface is well smoothed; reddish grey, brown, greyish brown, very dark grey. Slight burnishing (self-slip) is preserved in some places. The inner surfaces are well smoothed; very dark greyish brown, very dark grey, greyish brown. Fractures are black. Decoration - a zigzag composition covering the whole vessel except the rim edge and the bottom part. It is formed of horizontal belts filled with parallel diagonal deep incised lines less $1 \mathrm{~mm}$ wide. Deep pits made using a ribbed-end stamp are on the lip (Fig. 10). There are imprints of elderberry (cf. Sambucus) seeds on the outer surface (Endo et al. in prep.).

\section{$B a z k-7 t$}

The sample is a decorated fragment of a wall (field inventory No. 210 , sq. C/14, depth $0.7 \mathrm{~m}$ ) of vessel 21. There are 19 fragments of this vessel in the collection. Most of them were found in a compact cluster in zone $\mathrm{X}$ at a depth of $0.9-0.99 \mathrm{~m}$ (Figs. 6, 7).

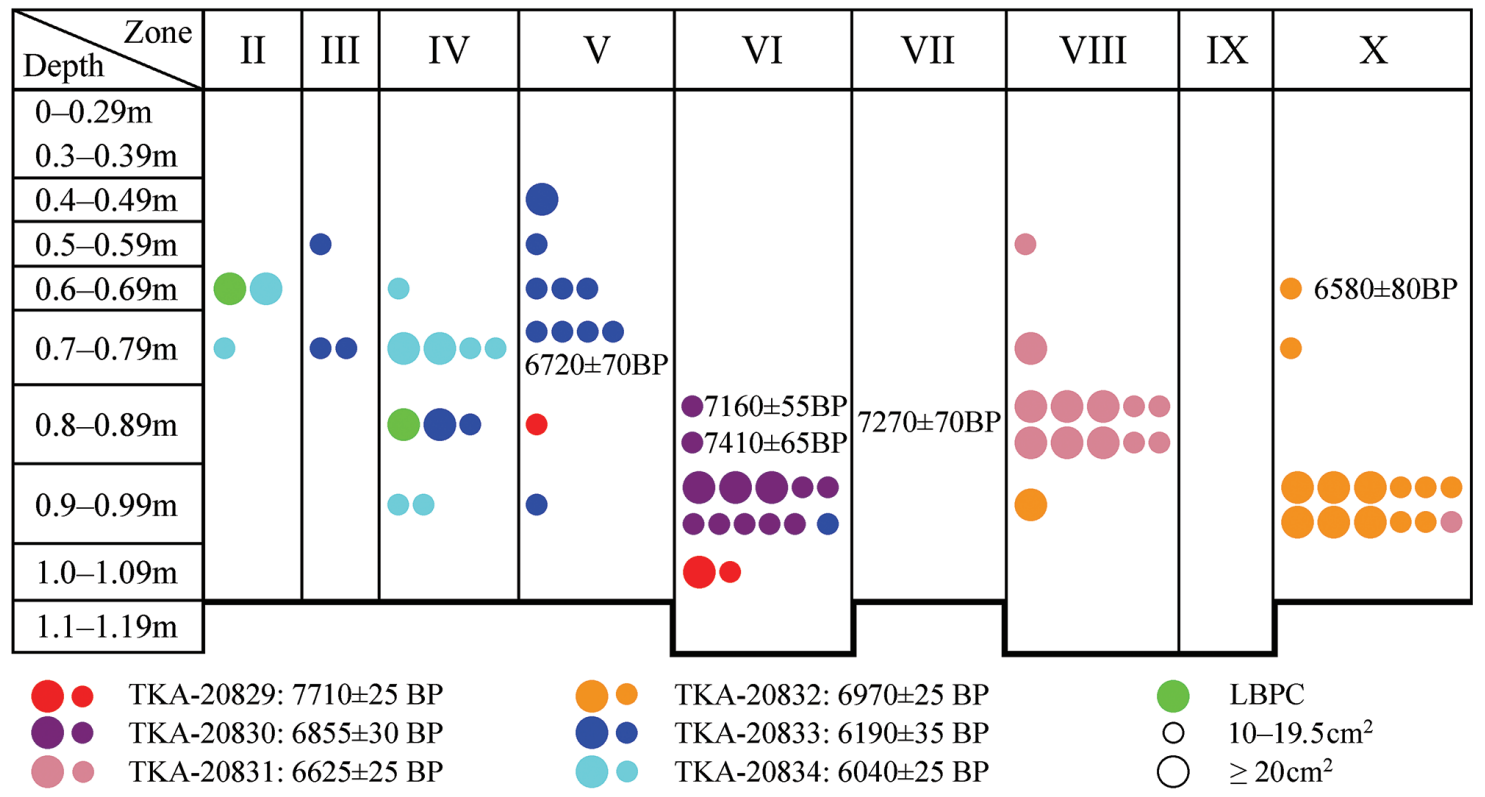

Fig. 7. Bazkiv Ostriv. Scheme of the vertical location of the sherds of dated vessels. 


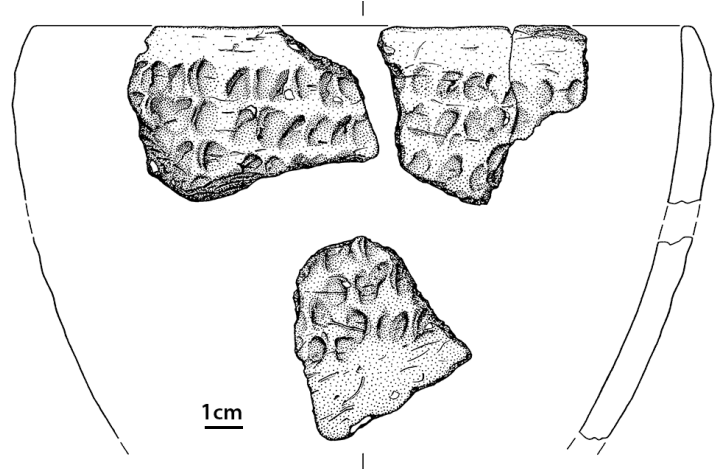

Fig. 8. Bazkiv Ostriv. Vessel 23 dated by sample Bazk-4t.

The vessel can be reconstructed as a pot with a slightly inverted rim, cylindrical upper part with a diameter of about $30 \mathrm{~cm}$, which is connected to the inverted conical lower part through a pronounced body corner. The lip is rounded, straight. The bottom is missing. The wall thickness is $0.8-1.0 \mathrm{~cm}$. The pottery paste contains an admixture of thin organic fibres, isolated waterworn pebbles, a lot of large fragments of shells (up to $0.7 \mathrm{~cm}$ ). The outer surface is slightly burnished (self-slip); pinkish grey, red, dark brown. The inner surface is well smoothed, grey. The fractures are black. Decoration - composition of vertical bundles consisting of seven parallel wavy deep incised lines $2-3 \mathrm{~mm}$ wide. Each line begins and ends with a deep pit (Fig. 11).

\section{Bazk-8t}

The sample is a fragment of a wall (field inventory No. 6, square F/1-2, depth $0.7 \mathrm{~m}$ ) of vessel 2 . In the collection, the vessel is represented by 32 fragments found within zones III, IV, V, VI. But the majority

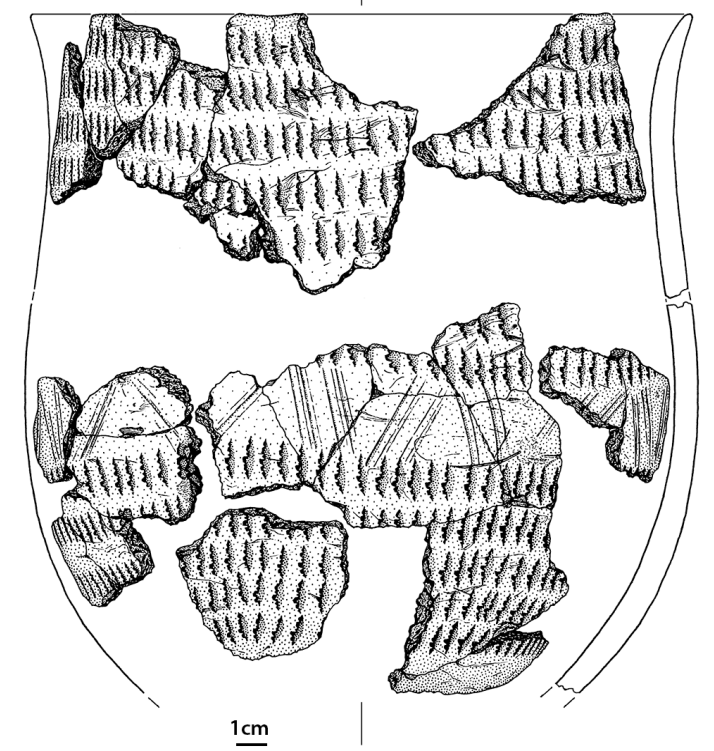

Fig. 9. Bazkiv Ostriv. Vessel 1 dated by sample Bazk-5t. of them lay in the sufficiently compact cluster in squares $\mathrm{U}-\mathrm{H} / 1-4$ in zones III and $\mathrm{V}$ at a depth of $0.5-0.79 \mathrm{~m}$ (Figs. 6, 7). The vessel is reconstructed as a pot with a truncated ovaloid body of maximum diameter $22 \mathrm{~cm}$. The everted rim is of $19 \mathrm{~cm}$ diameter. The lip is rounded, slightly undulate. The bottom is missing. The wall thickness is $0.6-0.8 \mathrm{~cm}$. The pottery paste contains a lot of sharp-cornered gravel (up to $0.6 \mathrm{~cm}$ ), sand and organic fibres as well as a little mica and small grains of red ochre. The outer surface is reddish brown, pinkish grey, greyish brown. The inner one is black, very dark grey, dark reddish grey, pinkish grey. The fractures are generally black. Both surfaces are well smoothed and slightly burnished (self-slip). Decoration - grid consisting of bundles of diagonal lines superficial incised by a notched stamp on the exterior rim face; rectangular zones filled with horizontal rows of impressions made with that stamp on the vessel body; and sparse diagonal lines drawn by the same stamp on the bottom part (Fig. 12).

\section{Bazk-9t}

The sample is a decorated fragment of a wall (field inventory No. 38, square B/5, depth -0.65 ) of vessel 39 . There are 12 fragments of this vessel in the collection. They were found within zones II and IV. Except for two shards, the rest lay at a depth of 0.6$0.79 \mathrm{~m}$ (Figs. 6, 7). Only the restricted upper part of the probably truncated ovaloid vessel has been preserved. The maximum diameter is $19 \mathrm{~cm}$. The vertical rim is of $13 \mathrm{~cm}$ diameter. The lip is rounded, straight. The wall thickness varies from $0.5 \mathrm{~cm}$ to $1 \mathrm{~cm}$. Pottery paste is oversaturated with sharp-cornered gravel (up to $0.4 \mathrm{~cm}$ ), sand and mica. A small amount of thin organic fibres is there too. The outer surface is well smoothed; light reddish brown, greyish brown, very dark greyish brown. The inner one and fractures are black. Decoration - a diagonal grid pattern, which is on all available potsherds. It is formed of superficial incised lines of 1-2mm wide. One horizontal row of comb stamp impressions is on the thinned interior rim edge (Fig. 13).

\section{Bazk-9c}

The sample of charred organic residue in the form of a very thin black coating was scraped off the inner surface of the potsherd, which is the sample of Bazk-9t.

\section{Method}

Sample preparation for radiocarbon dating was conducted following the methods of Yoshida $e t$ al. 
(2004). About several millimetres of the potsherd's surface was shaved using a grinder, and then thrown away to remove impurities on the earthen vessel. The sample of about $200-300 \mathrm{mg}$ was cut off by using a diamond cutter, corresponding to $0.5 \mathrm{~cm}^{2}$ of $1 \mathrm{~cm}$ thickness. The potsherd was divided into exterior and interior surface portions and the internal black portions were subjected to a series of experiments. To remove the contaminants for ${ }^{14} \mathrm{C}$ dating, samples were subjected to acid-alkali-acid (AAA) pre-treatment at $80^{\circ} \mathrm{C}$. The process was the same as that described in Kunikita et al. (2007). The rates of chemical treatment for specimens are shown in Table 3. The concentration of the alkali treatment for the potsherd (organic temper in pottery) was adjusted to prevent the specimens from being slightly coloured by it. The concentration of the alkali treatment for the charred remains on pottery was also kept to a level at which the sample did not dissolve completely. The rate of $\mathrm{CO}_{2}$ in the refinement was kept within a range of $0.6-5.6 \%$ for a potsherd. The potsherd (organic temper in pottery) can be dated using the black-coloured inside part at $1.5-2.5 \%$ content (Yoshida et al. 2004). The measurements were taken using the compact AMS of the University Museum at the University of Tokyo. The radiocarbon results were calibrated using OxCal v4.3.2 (Bronk Ramsey 2017; Bronk Ramsey, Lee 2013).

\section{Results and discussion}

The results of the analysis are shown in Table 4. But before using them for clarification of the issue of the

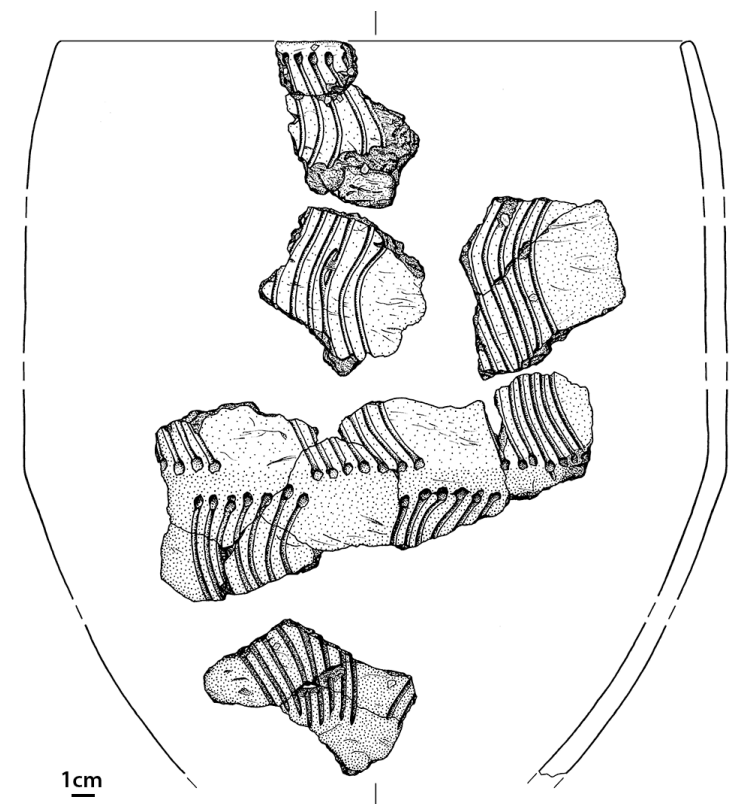

Fig. 11. Bazkiv Ostriv. Vessel 21 dated by sample Bazk-7t.

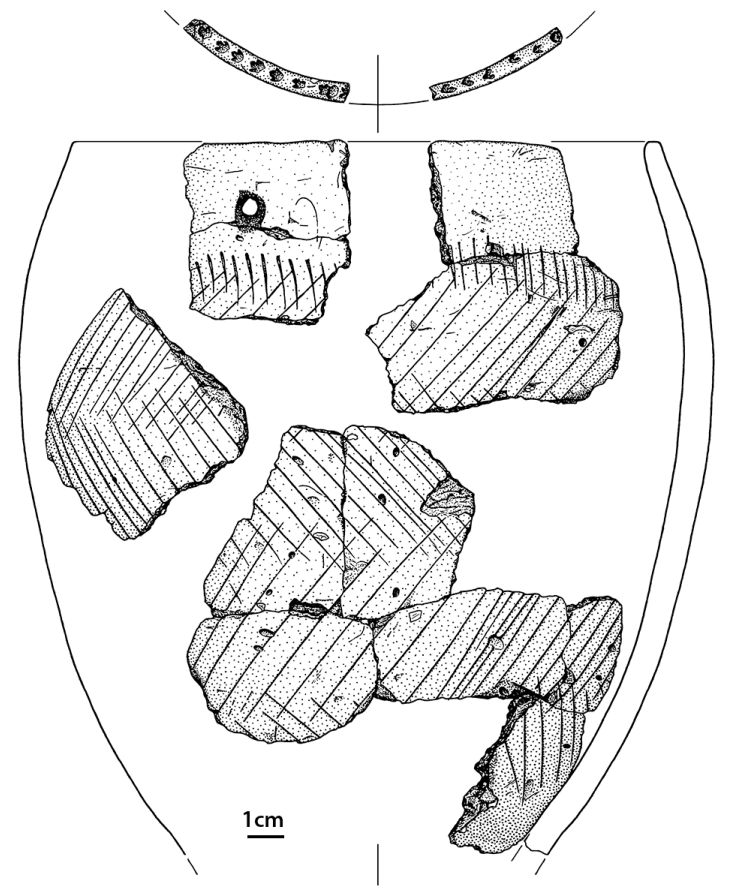

Fig. 10. Bazkiv Ostriv. Vessel 22 dated by sample Bazk-6t.

timeframe of the different BDC pottery traditions a preliminary assessment of their reliability should be carried out. It consists of the mutual verification of information obtained in various ways. Therefore we will consider the question of possible distortion of the real age of the samples and compare these data with the typological characteristics of the corresponding vessels and the stratigraphic context in which they were found.

Possible distortion of true age of the samples The origin of the carbon-containing materials in the pottery can be problematic, and it is important to verify if those materials are directly related to the archaeological context. Therefore, first, there is distinction to be made: is it indeed the direct dating of vegetable fibres, more or less contemporaneous with the production of the pot, or is it rather the carbon fraction of the sherd that has been dated? It is believed that geological signals are always difficult to separate completely from the archaeological ones, especially in those sherds that do contain not enough organic temper (Kulkova 2014.117). Thus, the relative carbon content in the measured samples plays a key role. A value of about 2-3\% is considered as such that the effect of the 'old' carbon from clay may be ignored (Yoshida et al. 2004.716).

Examining our samples from this view, only three measurements on fragments of vessel 22 (Fig. 10) and 39 (Fig. 13) from Bazkiv Ostriv as well as the 


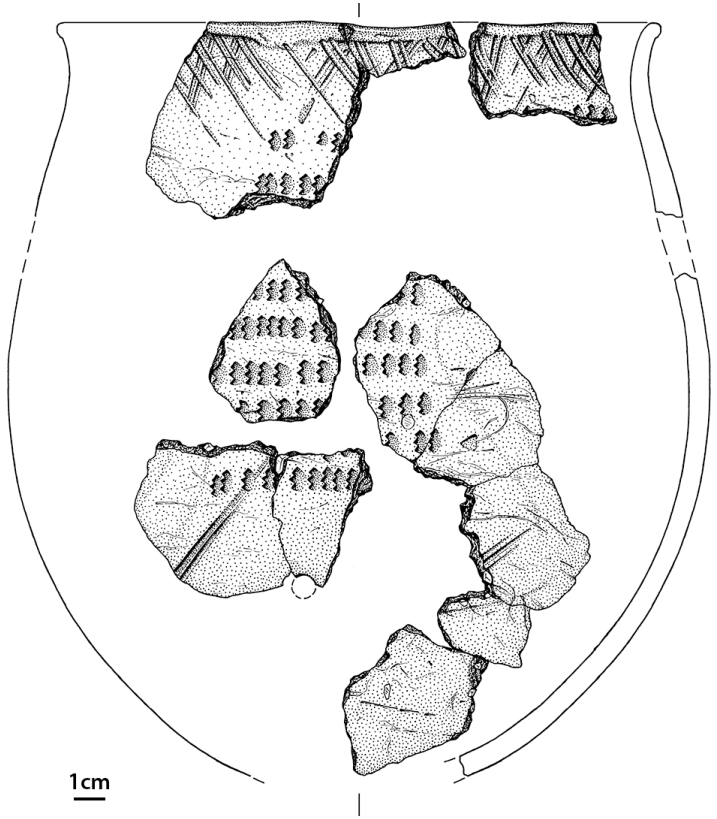

Fig. 12. Bazkiv Ostriv. Vessel 2 dated by sample Bazk-8t.

vessel from Shumyliv-Cherniatka (Fig. 2) can be recognized as the most reliable (Tab. 3; Fig. 14). The reliability of three more measurements on samples with the same $\mathrm{CO}_{2}$ content of $1.1 \%$ is moderate. These are obtained on fragments of vessel 16 from Hlynske I (Fig. 4), vessel 1 (Fig. 9) and vessel 2 (Fig. 12) from Bazkiv Ostriv. Measurements on samples of vessel 7 from Hlynske I (Fig. 5), vessel 23 (Fig. 8), and vessel 21 (Fig. 11) from Bazkiv 0striv with a $\mathrm{CO}_{2}$ content of $0.6-0.7 \%$ are the least reliable. It is noteworthy that these two samples gave the most controversial dates of the first half of $7^{\text {th }}$ millennium BC. Perhaps they are heavily overestimated due to the age of the geological carbon in their clay matrix.

Second, the real age of archaeological carbon, which is simultaneous with the time of manufacture and use of vessels, can be distorted by several factors (overviews: Bonsall et al. 2002; Philippsen 2015. 160-162). The main one is the freshwater reservoir effect (FRE). The most important mechanism of its origin is the dissolution of carbonate minerals, due to hard water, and thus the 'hardwater effect'. From such water, dissolved inorganic carbon gets into aquatic vegetation and further along the food chain into the organisms of molluscs, fish, crawfishes, turtles and river mammals. Therefore, the inclusions of river silt, algae and mollusc shells to ceramic paste can overestimate its true age.

Today, laboratory studies on the composition of the ceramic paste of vessels from more than a dozen BDC monuments have been published. For example, according to Alexander Bobrinsky and Irina Vasilyeva's identification, all 57 vessels they studied from eight BDC sites from the forest-steppe Buh area were made of river clay. Among them, 13 vessels are from Bazkiv Ostriv, six from Hlynske I and seven from Shumyliv-Cherniatka. In describing all the samples the presence of waterworn fine sand and "voids by the liquid organic fraction of silt" was noted. Imprints of algae were on all samples except one. Mollusc shells were found in the paste of most vessels (Bobrinsky, Vasilyeva 1998.216). Frequent use of silt, as well as the presence of imprints of 'aquatic vegetation' on $86 \%$ of the pottery from the Tătărăuca Nouă XV settlement, is mentioned by Larina. She also notes an admixture of crushed shells and small river pebbles in the ceramic paste (Larina 2006.37-38). But linking these results with concrete vessels and even with the type of pottery is impossible, since drawings or photos of the analysed samples have not been published.

Examining our nine pottery samples according to the above criteria visible with the naked eye in the fractures of corresponding vessels, the presence of shells is noted in five cases, rounded sand (possibly taken along with river mud) - in three cases, prints of thin, twisted curly threadlike fibres (algae?) - in eight cases (Tab. 5). On this basis, the vessels with lower carbon content also look potentially the most susceptible to the FRE, which increases our doubts about the validity of very old dates, measured on their shards.

The FRE distortion of a vessel's age can arise also due to penetration of the broth of cooked aquatic flora and fauna into its pottery structure as well as due to formation of a charred crust of the food of aquatic origin on its surface. Such contamination can be detected by special lipid residue analysis. Samples of eight of the nine measured vessels have al-

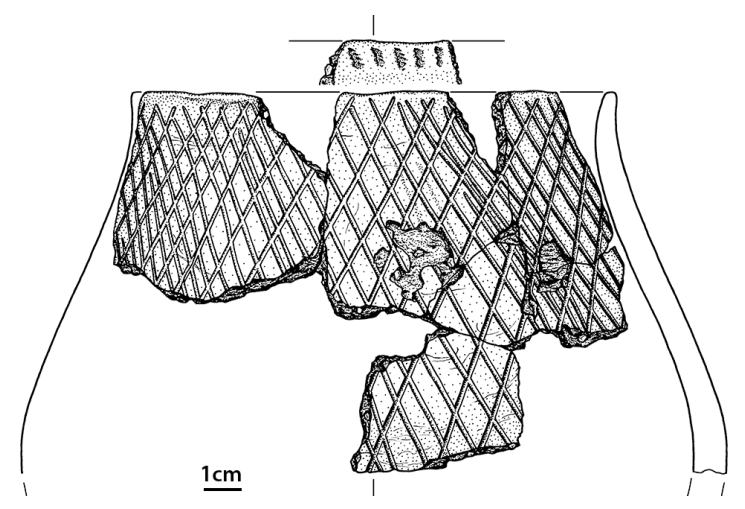

Fig. 13. Bazkiv Ostriv. Vessel 39 dated by samples Bazk-9c and Bazk-9t. 


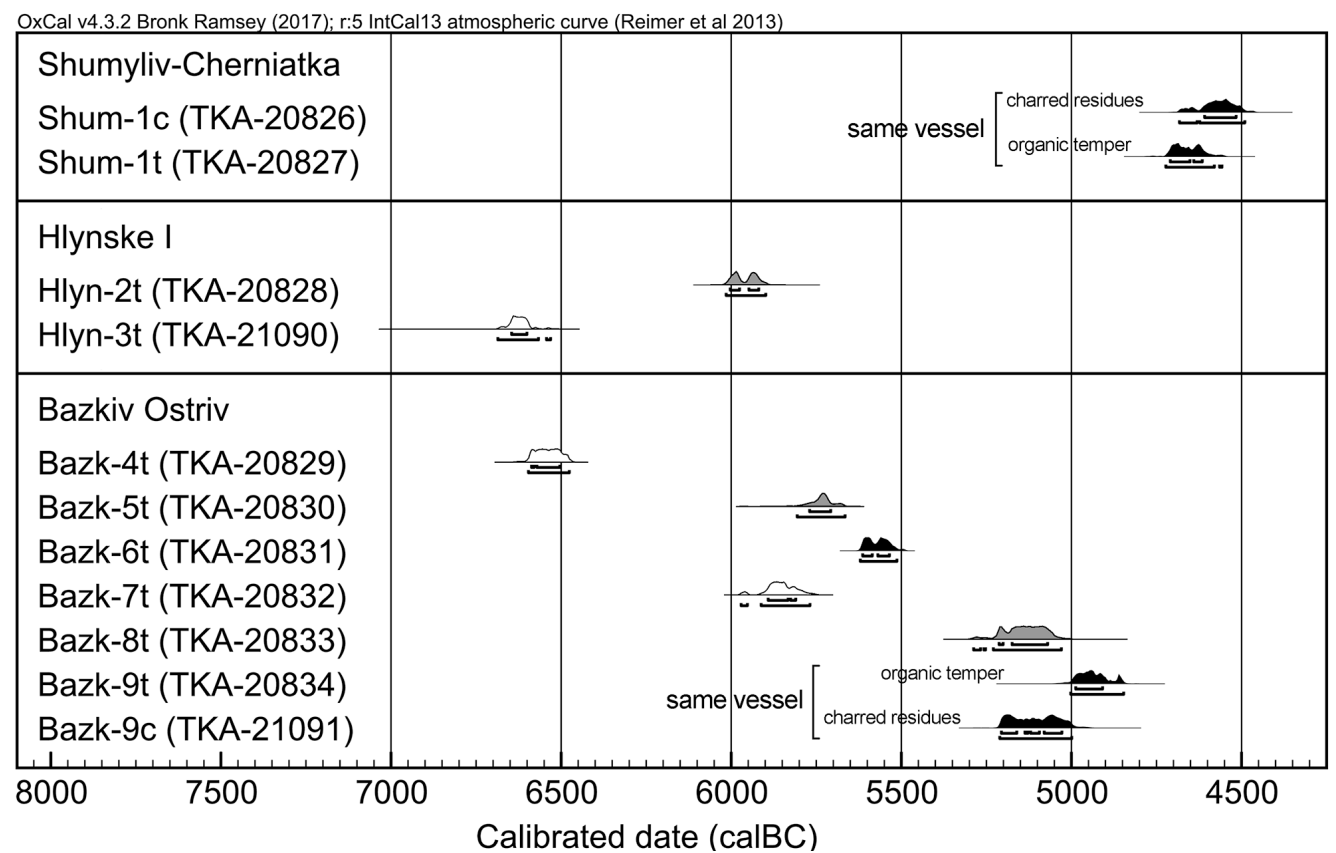

Fig. 14. Plot of the new AMS dates, measured on the samples with $\mathrm{CO}_{2}$ content of: white 0.6-0.7\%, grey $1.1 \%$, black $2.4 \%$ and more.

ready been transferred for such research, which is carried out by an international team led by Prof. Carl Heron within the scope of the project "The Innovation, Dispersal and Use of Ceramics in NW Eurasia".

Also, the 'old wood' effect can arise if carbon was sorbed from the fuel during the firing process when the clay paste had not yet hardened. In a similar way, during food cooking, the soot of old trees can get into the burnt food crust, overestimating its true age.

Taking into account these factors, which make the real age of the samples seem older, each of the dates we obtained (especially on samples with low carbon content and an abundance of freshwater shells) should be considered as not a precise time period, but terminus post quem - the earliest possible date of the corresponding vessel.

Various contaminations may have occurred due to young carbon getting into the potsherds from the surrounding soil matrix. It can dissolve in water and percolate through sediments, accumulating in both pottery paste and carbonized crust, underestimating their true age. Thorough chemical sample preparation usually ensures the removal of humic acids from the pore structure of the ceramic matrix, as well as from food carbon deposits on ceramics (Kulkova 2014.119). However, in this regard, the two youngest dates for the vessel from Shumyliv-Cherniatka deserve special attention. Danilenko's words about discovering it in grey-green sediments interpreted as 'ancient meadow-type soil' are worrying, as this differs from the 'yellow-grey loess-like loams' which contained the finds in the Hlynske I and Bazkiv Ostriv. Therefore, the slight young carbon effect cannot be ruled out completely here.

\section{Comparing the new dates with absolute chro- nology and archaeological context}

The plot of our dates clearly shows that they group four separate clusters (Figs. 14, 15).

The first cluster is formed by two dates, falling into the second quarter of the $7^{\text {th }}$ millennium BC. Today, they are the earliest for the culture as a whole, and are even somewhat earlier than the dates of the Late Mesolithic monuments of Soroca II, layer 2 and 3; Ziankivtsi II, the lower layer (Tab. 1).

The first date, TKA-21090: 7795 \pm 30 BP (6686-6532 cal BC), was measured on vessel 7 with the Skybyntsi type characteristics from the Hlynske I site (Fig. 5). Danylenko referred it to the Pechera phase of his periodization due to the finding of the Criş-like bowl there. However, the discussed date turned out to be at least 500 years older than the result of direct dating on the mentioned bowl. Thus, either we are dealing with a palimpsest, or with some distortion of the true age of the sample. The latter seems more likely because of the extremely low carbon content and abundance of shell in its pottery paste. Also, it is supported by the stratigraphic position of the few mate- 


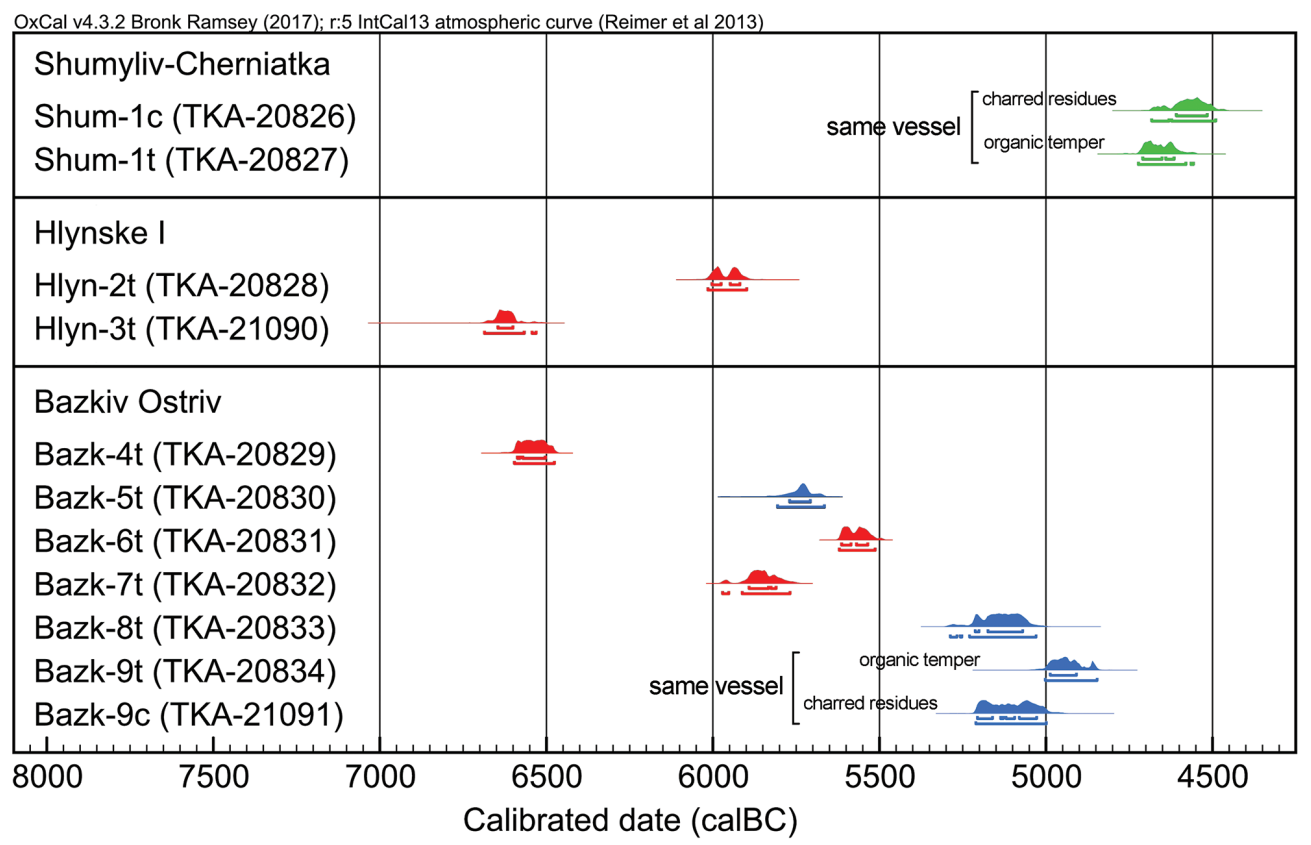

Fig. 15. Plot of the new AMS dates. Red: the Skybyntsi and Pechera type; blue: the Samchyntsi type; green: the Savran type.

rials in Complex 1, forming a cultural layer lying at a depth of more than $3 \mathrm{~m}$. Moreover, it is noteworthy that not one flint artefact characteristic to the local Mesolithic Kukrek culture was found there (Gaskevych $2017 a$ ).

Pottery contemporaneous with the date under discussion is known in Europe only in the Rakushechnyi Yar site on the Lower Don River, the KairshakTenteksor group monuments near the Volga River delta, the sites of the Elshanka Culture on the Middle Volga, as well as in the Serteya sites in the basin of the upper Western Dvina River. But the style of those vessels is defined as predominantly no decorated, or decorated in a way which shows no close analogies to the ornamentation of vessel 7 from the Hlynske I (Vybornov 2008; Mazurkevich, Dolbunova 2015). The only archaic-looking feature that brings them together is the rows of small pits set along incised lines. However, smoothly curved meander incised compositions themselves are characteristic not of the eastern hunter-gatherers, but the Danube-Carpathians farming cultures of the linear circle dated no earlier than the middle of $6^{\text {th }}$ millennium BC.

The second date, TKA-20829: 7710 \pm 25 BP (65976477 cal BC), was measured on vessel 23 with pinches from Bazkiv Ostriv (Fig. 8). There, it lay deeper than the other 11 dated items with known depths (Fig. 7). Since its discovery, it has been considered one of the oldest pots of the culture. But at the same time, Danylenko linked the origin of the decoration with pinches in the BDC with influence from the Criş-Körös-Starčevo area (Danilenko 1969.68-69). That simple pattern is known almost everywhere in the Balkans-Danube-Carpathians during all the Early Neolithic periods. In particular, vessels with pinches are in the materials of the most eastern Cris monuments located in Moldova, approx. $130 \mathrm{~km}$ from Bazkiv Ostriv (Dergachev, Larina 2015.Tab. 10, 32, 49, $80)$. However, the age of the measured fragment turned out to be older not only than their ${ }^{14} \mathrm{C}$ dates (Kovalenko 2017.157, 158, Tab. 1), but all reliable dates of the Early Neolithic monuments in the whole Danube catchment (Thissen 2009). In areas east of the Buh, prototypes of this decoration are also not known. Therefore, such an old date should be explained either by distortion of the true age due to the extremely low carbon content and presence of shell temper, or by an unlikely direct cultural impact from the Near East, where vessels of similar shape adorned with pinches and fingertip impressions are found at some sites dated to the first half of the $7^{\text {th }}$ millennium BC, for example, Tell el-Kerkh (horizon Rouj 2a-2b) in the Rouj River basin in North-Western Syria (Tsuneki 2012.34-36).

The next cluster is formed by four dates that point to the first half of $6^{\text {th }}$ millennium $\mathrm{BC}$.

The first date, TKA-20828: 7080 \pm 30 BP (6016-5899 cal $\mathrm{BC}$ ), was measured on sherds of the possible Cris 'import' vessel 16 from Complex 1 in the Hlynske I site (Fig. 4). Its main features are the dark burni- 
shing, carinated form, and a pedestal. Based on this, Kotova (2015.61) has seen analogies to it in several partially preserved bowls with a more-less pronounced body corner from the Koprivets and Blagotin site in the Balkans, dated to a slightly older time than our date shows. The bottom shape of these bowls is unknown. The closest analogies of vessel 16 in terms of technology, form, decor, and metric parameters are noted in the materials of the Körös monuments of Eastern Hungary (Gaskevych 2008a.294; $2017 a$. 107), for example, Furta-Csátó (Makkay 1990.Pl. 3, 5; Makkay et al. 2007.Fig. 132.7-9, Fig. 134.6). Due to the presence of pottery with so-called 'Protovinča' traits there, they may be synchronous with the early phases of the Vinča culture, dated no earlier than 5300 BC (Reingruber 2018.85-88), or slightly precede them. In this case, the joint occurrence of vessels 16 and 7 (with some possible traits of the linear pottery) within Complex 1 does not cause contradictions. Therefore, in general, the discussed date may be considered overestimated due to the distortion of its true age. Based on the composition of the clay paste (Tab. 5) and the likely use as 'tableware' rather than 'kitchenware', it is least affected by FRE. On the other hand, the probable western or southwestern origin of this vessel may indicate that it was made in the limestone and chalk rich landscapes of the Moldavian and Moesian Platform, or mountain systems of the southern and western Carpathians, where the powdered carbonaceous bedrock with no radiocarbon content could get into the pottery paste directly. However, verification of these assumptions requires special in-depth analyses using natural science methods.

The second date, TKA-20832: 6970 25 BP (5972$5769 \mathrm{cal} \mathrm{BC}$ ), was measured on vessel 21 with vertical incised wavy lines (Fig. 11), which was found in the western part of the Bazkiv Ostriv settlement. On zone $\mathrm{X}$, its large fragments lay compactly at a depth of $0.9-0.99 \mathrm{~m}$ corresponding to the oldest (the Skybyntsi after Danylenko) layer. The "fragment of red deer horn" with a younger date of $6580 \pm 80 \mathrm{BP}$ (Ki-8169) was found above in this zone (Fig. 7). This is in favour of the possible reality of the discussed date, despite the extremely low carbon content and abundance of coarse shell fragments in the clay paste of the sample. A distant analogy of this pot decoration may be seen in a vessel from the 'lower Neolithic' layer in Gard, the direct dates on the pottery from which fall into the second and third quarter of the $6^{\text {th }}$ millennium BC. Parallel wavy lines on the upper cylindrical part of the body of that vessel were also grouped into bundles of seven pieces each (Tov- kaylo 2014.Fig. 11.2). But an admixture of very coarse sand and granules, not shells, is in its paste.

The third date, TKA-20830: 6855 \pm 30 BP (5807-5666 cal $\mathrm{BC}$ ), was measured on vessel 1 with comb impressions (Fig. 9) from the northern part of Bazkiv 0striv. There, in zone VI, its large fragments lay compactly $10 \mathrm{~cm}$ above the large fragments of vessel 23 given one of the earliest dates. However, bone samples measured to the end of the $7^{\text {th }}$ millennium $\mathrm{BC}$ (Ki-6652 and Ki-8166) lay 10-20cm above discussed vessel 1 (Fig. 7). Despite this, Kotova has attributed the last to the 'upper Neolithic' layer, but the dates to the 'lower' one (Kotova 2003.208, Fig. 42.1). For us, this fact may be explained either by the mixture of materials of different times in that part of the monument or by significant distortion of the real age of the bones due, for example, to FRE. Anyway, this date questions the traditional synchronization of the Samchyntsi-type pottery exclusively with the postCris time. This is in agreement with the deep occurrence of the vessel that was found nearby shards of the Skybyntsi type pottery. The latter probably explains why such a representative well-preserved vessel has never been mentioned and published by Danylenko, the author of the BDC basic periodization.

The fourth date, TKA-20831: 6625 \pm 25 BP (56215514 cal BC), was measured on vessel 22 with incised linear zigzag decoration (Fig. 10) from zone VIII in Bazkiv 0striv. There, its large fragments lay above vessel 21 with a slightly older date (Fig. 7). The pot under discussion was published by Danylenko as belonging to the Skybyntsi-type (Danilenko 1969.70). The motif of its decoration has analogies among the vessels from the nearest Criş monuments in Romanian Moldova (Ursulescu 1984.Pl.15.5, 43. 25; Comşa 1991.Fig.4.3, 14, 17; Popussoi 2005.Fig. 59.4, 72.7, 73.2, 82.8, 83.4, 83.7, 95.4, 102.5, 109.1), and the neighbouring Republic of Moldova (Dergachev, Larina 2015.Tab. 20.8, 50.4,11,13,14, 76.3,4). The radiocarbon age of Trestiana, Level I (GrN-17003: $6665 \pm 45$ BP) and Sacarovka 1 (including one conventional Kyiv date Ki-13899a: $6590 \pm 180 \mathrm{BP}$ on organic inclusions in pottery paste) fall in the range 5840-5450 BC (Mantu 1995.226; Kovalenko 2017. Tab. 1) that is roughly synchronous with the date of vessel 22. In addition, the date coincides with the direct dates on pottery with the same admixture of coarse shell fragments from the Gard site (Tovkaylo 2014.199-201).

The third cluster is formed by three dates of the Samchyntsi-type vessels from the Bazkiv Ostriv site, fal- 
ling into the end of the $6^{\text {th }}$ to the beginning of $5^{\text {th }}$ millennia BC.

The first date, TKA-20833: 6190 $\pm 35 \mathrm{BP}$ (5288-5030 cal BC), was measured on potsherd of vessel 2 decorated with comb impressions (Fig. 12). Large fragments of the LBPC fine bowl were found at the same depth with a large fragment of this vessel in zone IV. The second date, TKA-20834: 6040 25 BP (5211-

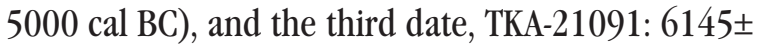
$35 \mathrm{BP}(5003-4847 \mathrm{cal} \mathrm{BC})$, were measured on organic inclusions in pottery paste and charred residues on the inner surface of vessel 39 with the incised diagonal grid pattern (Fig. 13). Its large fragments were found at the same depth with large fragments of the above-mentioned LBPC bowl in zone II (Figs. $6,7)$. Since all three dates concur to the time of local LBPC monuments with a 'musical note' pottery (Sapozhnikov, Sapozhnikova 2005.91.Tab. 1; Kiosak, Salavert 2018.122) their age can be considered true. In addition, the first date is consistent with the conclusion about the presence of painted vessels reproducing the Szakálhát culture ceramics from the Tisza River basin on the monument (Gaskevych 2017b).

Finally, the fourth cluster is formed by two dates, TKA-20826: 5725 \pm 30 BP (4683-4491 cal BC) and TKA-20827: $5805 \pm 25$ BP (4723-4558 cal BC), measured on Savran-type vessel from Shumyliv-Cherniatka (Fig. 2). They point to the second quarter of the $5^{\text {th }}$ millennium $\mathrm{BC}$; those are the youngest reliable measurements for the BDC. Excavating the site Danylenko noted the occurrence of materials of both the BDC, and Trypillia A of the Sabatynivka II type at the same depth, but not mentioned their possible synchronism. However, our dates fall into the range that coincides with the generally accepted dating of the Precucuteni II - Trypillia AIII (Mantu 1995.228; Rassamakin 2012.22-24), and they are even much younger than the range of Kyiv dates on bones from the eponymous Sabatynivka II settlement (Telegin et al. 2000.66). Thus, it confirms Tringham and Tovkaylo's views concerning the longterm synchronism of the late Buh-Dnister and early Trypillia monuments in the Buh area. With that, assuming the finds of BDC and Trypillia A form a homogeneous complex in the Shumyliv-Cherniatka (as has been asserted by Tovkaylo regarding the sites of Gard, Gard III, Puhach I, and others) seems too bold.

\section{The issue of the BDC pottery types time frame} Summing up the assessment of the reliability of dates from both a technical point of view and their correspondence to the typology and archaeological context, it should be recognized that the most valid in our series are the five youngest dates for two vessels of the Samchyntsi type and one of the Savran type. They are obtained on samples with satisfactory carbon content. There are no (Bazkiv Ostriv) or just a small number (Shumyliv-Cherniatka) of shells in their pottery paste. Also, the dates of the Samchyntsi vessels correspond to their occurrence on the same level with the LBPC materials in Bazkiv Ostriv, and the Savran vessel - with Trypillia finds in Shumyliv-Cherniatka. Moreover, the reliability of four of them is confirmed by the coincidence of the dates measured, one on carbonized crust on the surface and the other on organic inclusions in the paste of the same vessels. So, two dates from Shumyliv-Cherniatka giving with $95 \%$ confidence level showed significant overlap in the interval of 4683-4558 cal BC. Although the overlap of the dates of vessel 39 from Bazkiv Ostriv is only three years in the range 5003$5000 \mathrm{cal} \mathrm{BC}$, these results are very close, too. It thus seems that these dates correspond to their real age. These dates turned out to be much younger than the Kyiv dates obtained on bones from the 'upper Neolithic' layer from Bazkiv Ostriv, the 'dwelling' from the eponymous Savran site, the 'late Neolithic' or the 'Savran phase' settlements of Mykolyna Broiaka, Puhach II and Gard III. Three possible explanations can be proposed for this contradiction.

(1) A reassessment of the age of dates on bones due to the influence of FRE cannot be ruled out. Publishing a large set consisting of $33 \mathrm{Kyiv}$ dates measured on bones, the researchers mentioned the species of corresponding animals in five cases only. These are two samples of the omnivorous wild boar and two samples of the horns of the herbivorous deer from Bazkiv 0striv, as well as one sample of the herbivorous Bos or Equus from Hirzhove (Tab. 1). Thus, the most reliable Kyiv dates on bones are the last three only. Of these, two dates for Bazkiv Ostriv fall into the second and third quarters of the $6^{\text {th }}$ millennium BC, and the date for Hirzhove into the second half of the $7^{\text {th }}$ millennium BC. Any of the other dates on the animal bones could be measured by a sample that is the remains of a wild or domestic animal constantly or occasionally feeding on aquatic plants, animals, and mollusks. This is evidenced by the published species identification of the bones from nine Southern Buh monuments with mixed materials of different times (Bazkiv Ostriv, Mytkiv Ostriv, Mykolyna Broiaka, Puhach I, Puhach II, Gard III, Gard IV, Nova Mykolaivka-1, Dobrianka-3). In particular, a turtle, otter, beaver, bear, badger, wild 
boar, domestic pig, and dog are included in these lists (Danilenko 1969.Tab. 1; Tovkaylo 2005.Tab. 6.1; Gaskevych, Zhuravlev 2008.174; Zaliznyak et al. 2013.245). Humans are also omnivorous mammals who eat fish. Burials associated with the BDC were found on the Southern Buh sites Samchyntsi I, Gaivoron-Polizhok (Solgutiv Ostriv), Sokiltsi VI (Gaskevych 2015), and Dobrianka-3 (Zaliznyak et al. 2013.242). The date was measured only for the burial from Dobrianka-3. It falls into the last quarter of the $7^{\text {th }}$ millennium BC (Lillie et al. 2009.260). However, it cannot be ruled out that some unidentified human bones could be found on this and other sites and were ${ }^{14} \mathrm{C}$ dated. Therefore, all Kyiv dates, made on the basis of material which is referred to in publications as just 'animal bone', are generally doubtful.

(2) The uncertainty or lack of real cultural stratigraphy, as well as the mixing of materials of different times on many monuments, could lead to the erroneous correlation of the complexes of finds to the 'upper' and 'lower' layers and become the cause of the contradiction under discussion.

3 It is possible that the real time-space of the existence of the Samchyntsi and Savran type pottery was longer than is traditionally considered. In this case, both groups of the corresponding dates may be correct, but the relative chronology that correlates such vessels with only the post-Cris time is erroneous. This explanation is also supported by our less reliable AMS date on vessel 1 from Bazkiv Ostriv (Fig. 9), as well as Kyiv dates on the pottery from Gard and Dobrianka-1.

Even more complicated is the issue of the dating of the Skybyntsi and Pechera type pottery. The date on the only Skybyntsi-type sample with satisfactory carbon content, obtained from vessel 22 in Bazkiv 0striv (Fig. 10), points to the third quarter of the $6^{\text {th }}$ millennium BC. This is entirely consistent with the dates for the Criş settlements Sacarovka 1 and Trestiana, Level I (Mantu 1995.226; Kovalenko 2017.Tab. 1), recognized as 'Criş IV' after the Lasarovici periodization, or phenomenon like the 'Glăvănesti culture' or 'Prut-Danube culture', after Agathe Reingruber (2016.169; 2017.96-97). The established synchronization does not contradict the traditional view of the dating of the beginning of the BDC and its origin under the Balkan-Carpathian influence. It also corresponds to direct Kyiv dates on the Pechera type pottery from Gard. Thus, a comparison of this vessel with the Kyiv dates of the second half of the $7^{\text {th }}$ millennium BC, measured on the 'animal bones' from the 'lower layer' of the site (Kotova 2003.27$28,205)$, seems erroneous. Perhaps this was due to the mixing of the Skybyntsi finds with unrecognized late Mesolithic materials or a distortion of the real age of bones (which were published without identification) influenced by the FRE.

Unfortunately, all the other dates for the Skybyntsi and Pechera type pottery were measured on the samples with medium or very low carbon content (Tab. 3), which undermines their reliability. Thus, for example, the strong influence of 'geological' carbon can be clearly revealed for the date of the carinated bowl with features of the Vinča traditions from Hlynske I (Fig. 4). Such influence could even more strongly change the real age of the two oldest samples with an abundance of shell in their pottery paste (Figs. 5, 8). Therefore, the chronology of the corresponding vessels should be determined taking into account typological arguments.

Today, various possible scenarios of the origin and spread of the earliest pottery in the vast territory of Eastern Europe are debated. More traditionally it is seen as a component of the cultural complex of the Middle East agricultural population who moved to the northern Balkans and south-western Carpathian basin. It is believed that such pottery is not earlier 6200 BC (Budja 2009.126). For more ancient ceramic production three variants are proposed. Two of them are: its independent invention by mobile and semi-mobile hunter-gatherers in many centres in Eurasia and Africa; or its spreading to local foragers from one starting point that arose in East Asia as early as the Pleistocene around $14500 \mathrm{BC}$ (overviews: Jordan, Zvelebil 2009; Budja 2013). The main common features of this old pottery are a pointed or conical base, the predominantly bag-like form, covering of the whole outer surface by impressed decoration or another relief-like structure (Piezonka 2015. 286-287). According to a recently proposed third variant, one part of the oldest East European pottery is a component of a near-eastern 'Neolithic package', which had already arrived here directly from one or more unknown sources in the first quarter of

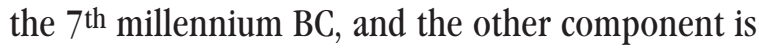
the result of its further development by indigenous hunter-gatherers (Mazurkevich, Dolbunova 2015). An important argument for this is the predominantly flat bottom shape of the most ancient vessels in various parts of the region.

Paradoxically, among BDC pottery in the Southern Buh area 'archaic' features of the oldest forager ce- 
ramics are more typical of exclusively point- and round-bottomed vessels of the Samchyntsi type, and have given reliable direct dates of the end of $6^{\text {th }}$ millennium BC. In contrast, there is only one reliable point-bottomed vessel (No. 38 from Bazkiv Ostriv) among the earlier pottery of the Skybyntsi and Pechera type. It is decorated with smoothly curved meander compositions formed by bundles of incised lines (Danilenko 1969.Fig. 24.4,6). This ornamental pattern has no analogies within foragers' assemblages to the north or east, but is a characteristic feature of some cultures of the linear circle, such as the Tiszadob Group and Bükk Culture in the Carpathian Basin (e.g., Piatnicková 2015). Perhaps it and some other peculiar forms of decoration, for example, vertical wavy lines covering the whole of a vessel's surface, appeared earlier not in the west, but just in the Southern Buh, which was proposed by Reingruber (2018.90). Therefore, to determine the place of origin and the distribution vector of the described traditions, reliable direct dating of the BDC pottery should be continued.

\section{Conclusion and prospects}

The set of 11 new AMS dates has given a wide scatter of their values within the entire period outlined by the previous BDC dates. Moreover, the two results of the second quarter of the 7 th millennium $\mathrm{BC}$ are beyond it and may potentially be the oldest dates of the culture. However, analysis of the samples from the aspect of carbon content, their susceptibility to the influence of the FRE, correspondence to the stratigraphy of the sites and typology of materials detected only six more credible dates. Their order on the timeline coincides with generally accepted ideas about the sequence of existence of the different BDC pottery types. The youngest is the vessel of the Savran type from Shumyliv-Cherniatka that gave two dates, which fall into the range of 4723-4491 cal $\mathrm{BC}$, when the Trypillia culture bearers already populated the region. Two vessels of the Samchyntsi type from Bazkiv 0striv gave three dates within the range of 5288-4847 cal BC, which corresponds to their finding next to fragments of fine 'music-note' bowls of the LBPC. The vessel of the Skybyntsi type from Bazkiv Ostriv gave the oldest plausible date of 5621$5514 \mathrm{cal} \mathrm{BC}$, which corresponds to the age of the Criş monuments in neighbouring Moldova.

From a perspective of the problem that arose two decades ago after the publication of the 'new' Kyiv dates measured on bones, the AMS Tokyo dates better correspond not to the latter, but the primary, tra- ditional, absolute chronology of the BDC, and conventional Kyiv dates on pottery. Most likely the dates on a bone, pointing to the second half of the $7^{\text {th }}$ millennium BC, are related to the Final Mesolithic finds not separated by excavators in the palimpsests of some Southern Buh settlements in the 1950s, or sampling the bones of animals, exposed to the FRE. Thus, it appears that the long-discussed problem of the BDC chronology is concerned with not only the material of samples, as is considered now, but with the interpretation of results. In quick pursuit of impressive publications, numerous radiocarbon dates were offhandedly compared with the unlikely stratigraphy of settlements, and doubtful periodization schemes created under the paradigms of stadial development more than half a century ago.

Of course, 11 new dates can by no means be sufficient for reliably dating the three corresponding sites, not to speak of a whole BDC. They can only be the beginning of a long process aimed at the creation of a model that could be advanced for future testing. In such a study, particular attention should be paid to the question of the age of pottery with the high amount of shell, given the old values, which show dates from our series. Is it a cultural trait of older pottery, where shell temper has dominated? Or is it a technical shortcoming in the dating process? Another important issue is the time of appearance of the archaic-looking point- and round-bottomed pottery of the Samchyntsi type. Is it the oldest in the region, or do the previous dates measured on such vessels convey the age of the geological component in their ceramic paste? To answer these and other questions, new direct ${ }^{14} \mathrm{C}$ dating on pottery, accompanied by its petrographical, physical and chemical studies, and in particular lipid analysis, should be conducted. Also, if possible, detailed information about the species of animals whose bones were measured at Kyiv laboratory earlier and the localization of corresponding samples in the sites should be found and published for further analysis.

We thank staff of the Micro Analysis Laboratory, Tan-
dem Accelerator (MALT) and Radiocarbon Dating La-
boratory, the University Museum, the University of
Tokyo. We are also grateful to Dr. Alexander Gorelik
for his favourable comments and the anonymous re-
viewer for constructive criticism and very useful sug-
gestions.




\section{Reference}

Balossi Restelli F. 2006. The Development of 'Cultural Regions' in the Neolithic of the Near East: The 'Dark Faced Burnished Ware Horizon'. British Archaeological Reports IS 1482. Archaeopress. Oxford.

Biagi P., Zaliznyak L., and Kozłowski S. K. 2007. Old problems and new perspectives for the radiocarbon chronology of the Ukrainian Mesolithic? In V. Yanko-Hombach, I. Buinevich, P. Dolukhanov, A. Gilbert, R. Martin, M. McGann, and P. Mudie (eds.), Extended Abstracts of the Joint Plenary Meeting and Field Trip of IGCP521 and IGCP 481, Gelendzhik (Russia) - Kerch (Ukraine), September 817, 2007. Southern Branch of the Institute of Oceanology, Russian Academy of Sciences and Demetra Beneficent Foundation. Gelendzhik. Kerch: 27-30.

Bobrinsky A. A., Vasilyeva N. N. 1998. O nekotoryh osobennostyah plasticheskogo syr'ya $\mathrm{v}$ istorii goncharstva. In I. B. Vasilyev (ed.), Problemy drevney istorii Severnogo Prikaspiya. Izdatelstvo Samarskogo Gosudarstvennogo Pedagogicheskogo Universiteta. Samara: 194-218. (in Russian)

Bronk Ramsey C. 2017. OxCal v4.3.2. The Oxford Radiocarbon Accelerator Unit, University of Oxford.

http://c14.arch.ox.ac.uk/oxcal/0xCal.html

Bronk Ramsey C., Lee S. 2013. Recent and planned developments of the program 0xCal. Radiocarbon 55: 720730. https://doi.org/10.2458/azu_js_rc.55.16215

Bonsall C., Cook G., Manson J. L., and Saderson D. 2002. Direct dating of Neolithic pottery: progress and prospects. Documenta Praehistorica 29: 47-59.

https://doi.org/10.4312/dp.29.5

Budja M. 2009. Early Neolithic pottery dispersals and demic diffusion in Southeastern Europe. Documenta Praehistorica 36: 117-137. https://doi.org/10.4312/dp.36.7

2013. Neolithic pots and potters in Europe: the end of 'demic diffusion' migratory model. Documenta Praehistorica 40: 39-55. https://doi.org/10.4312/dp.40.5

Burdo N. B. 2002. Novye dannye dlya absolyutnoy datirovki neolita i rannego eneolita na territorii Ukrainy. Stratum plus 2: 431-446. (in Russian)

Comşa E. 1991. Aşezarea de tip Criş de la Valea Lupului. Arheologia Moldovei 14: 5-35.

Czerniak L., Gaskevych D., Józwiak B., and Domaradzka S. 2013. Neolityzacja międzyrzecza Bohu i Dniestru. Wstępne sprawozdanie z polsko-ukraińskich badań w latach 20082010. Gdańskie Studia Archeologiczne 3: 91-118.
Danilenko V. N. 1969. Neolit Ukrainy. Glavy drevnei istorii Yugo-Vostochnoi Evropy. Naukova Dumka. Kiev. (in Russian)

Dergachev V., Sherratt A., and Larina 0. 1991. Recent results of Neolithic research in Moldavia (USSR). Oxford Journal of Archaeology 10: 1-16.

https://doi.org/10.1111/j.1468-0092.1991.tb00001.x

Dergachev V. A., Larina 0. V. 2015. Pamyatniki kul'tury Krish Moldovy: (s katalogom). Kishineu. (in Russian)

Endo E., Nasu H., Gaskevych D., Gershkovych Ya. Videiko M., and Yanevich 0 . In preparation. Ukraine as the crossroad for agricultural dispersal in Eurasia: Re-evaluation of plant impressions in pottery.

Fomenko V. M., Burdo N. B., and Spitsyna L. A. 2014. Bahatosharova pamiatka Tashlyk II. Arkheolohiia $i$ davnia istoriia Ukrainy 1(12): 137-147. (in Ukrainian)

Gaskevych D. L. 2005. Kremiani vyroby kukrekskoi kulturnoi tradytsii v inventari buho-dnistrovskykh pamiatok Pobuzhzhia. Arkheolohiia 3: 24-37. (in Ukrainian)

2006. Arkheolohichni rozvidky pamiatok buho-dnistrovskoi neolitychnoi kultury u 2003-2005 rr. In N. O. Gavryliuk (ed.), Arkheolohichni doslidzhennia v Ukraini 2004-2005 rr. Instytut arkheolohii NAN Ukrainy. Kyiv: 116-122. (in Ukrainian)

2007. Cynkhronizatsiia buho-dnistrovskoho neolitu ta neolitu Tsentralnoi Yevropy: Problema radiovuhletsevykh dat. In M. Gierlach, L. Bakalarska (eds.), Wspólnota dziedzictwa archeologicznego ziem Ukrainy $i$ Pol$s k i$. Materiały z konferencji (Łańcut, 26-28 X 2005 r.). Krajowy Ośrodek Badań i Dokumentacji Zabytków. Warszawa: 115-147. (in Ukrainian)

2008a. Forma dna keramichnoho posudu buho-dnistrovskykh pamiatok Lisostepovoho Pobuzhzhia. Arkheolohycheskyi almanakh 19: 275-307. (in Ukrainian)

2008b. Keramika «samchynskoho» typu ta problemy periodyzatsii buho-dnistrovskoi neolitychnoi kultury. Kamiana doba Ukrainy 11: 157-187. (in Ukrainian)

2010. Severo-pontiyskoe impresso: proishozhdenie neoliticheskoy keramiki s grebenchatym ornamentom na yuge Vostochnoy Evropy. Stratum plus 2: 213-251. (in Russian)

2011. A new approach to the problem of the Neolithisation of the North-Pontic area: is there a north-eastern kind of Mediterranean Impresso pottery? Documenta Praehistorica 38: 275-290. https://doi.org/10.4312/dp.38.22 
2012. Melnychna Krucha - bahatosharova pamiatka pervisnoi doby na pivdni lisostepovoho Pobuzhzhia. Arkheolohiia i davnia istoriia Ukrainy 8: 13-22. (in Ukrainian)

2013. V. M. Danylenko ta periodyzatsiia neolitu Pivdennoho Buhu: novi zapytannia do starykh dzherel. Arkheolohiia 4: 3-17. (in Ukrainian)

2014. Problemy radiovuhletsevoho datuvannia buhodnistrovskoi neolitychnoi kultury. Arkheolohiia 4: 317. (in Ukrainian)

2015. Pogrebeniya bugo-dnestrovskoj neoliticheskoj kul'tury: kriticheskij analiz istochnikov. Stratum plus 2: 181-206. (in Russian)

2017a. Hlynske I - neolitychna pamiatka na Pivdennomu Buzi (za materialamy doslidzhen 1955 ta 1957 rokiv). Arkheolohiia i davnia istoriia Ukrainy 3(24): 85-110. (in Ukrainian)

2017b. Keramika s rospis'yu v neolite Yuzhnogo Buga. Stratum plus 2: 231-255. (in Russian)

2017c. Reviziia stratyhrafii poselennia Bazkiv Ostriv yak osnovy periodyzatsii buho-dnistrovskoi neolitychnoi kultury. Kamiana doba Ukrainy 17-18: 188-215. (in Ukrainian)

Gaskevych D. L., Kiosak D. V. 2011. Neolitychni znakhidky Melnychnoi Kruchi z doslidzhen A. V. Dobrovolskoho ta kulturno-khronolohichna interpretatsiia pamiatky. Kamiana doba Ukrainy 14: 198-207. (in Ukrainian)

Gaskevych D. L., Zhuravlev O. P. 2008. Nova Mykolaivka-1 - nova neolitychna pamiatka u Lisostepovomu Pobuzhzhi. In L. V. Kulakovska (ed.), Doslidzhennia pervisnoi arkheolohii v Ukraini (Do 50-richchia vidkryttia paleolitychnoi stoianky Radomyshl). Korvin Press. Kyiv: 168175. (in Ukrainian)

Gorelik A. 2019. 'Neolitizatsiya' ili 'subneolitizatsiya' Severnogo Ponto-Kaspiya? Stratum plus 2: 369-381. (in Russian)

Jesse F. 2010. Early Pottery in Northern Africa - An Overview. Journal of African Archaeology 8(2): 219-238.

Jordan P., Zvelebil M. 2009. Ex Oriente Lux: The Prehistory of Hunter-Gatherer Ceramic Dispersals. In P. Jordan, M. Zvelebil (eds.), Ceramics before farming: the dispersal of pottery among prehistoric Eurasian hunter-gatherers. Left Coast Press. London: 33-89.

Kiosak D. 2016. Mesolithic 'Heritage' and Neolithic in Southwest Ukraine. In R. Krauss, H. Floss (eds.), Southeast Europe Before Neolithisation. Proceedings of the International Workshop within the Collaborative Research Cen- tres SFB 1070 "RessourcenKulturen", Schloss Hohentübingen, 9th of May 2014. Ressourcen Kulturen 1. Universität Tübingen. Tübingen: 131-147.

Kiosak D., Salavert A. 2018. Revisiting the chronology of two Neolithic sites in Eastern Europe: new radiocarbon dates from Melnychna Krucha and Kamyane-Zavallia (Southern Buh region, Ukraine). Revista Arheologică 14 (2): 116-131.

Kotova N. S. 2002. Neolitizaciya Ukrainy. Shlyah. Lugansk. (in Russian)

2003. Neolithization in Ukraine. British Archaeological Reports IS 1109. Archaeopress. Oxford.

2015. Drevneyshaya keramika Ukrainy. Maydan. Har'kov. Kiev. (in Russian)

Kovalenko S. I. 2017. O kul'turno-hronologicheskoy pozicii final'no-mezoliticheskih pamyatnikov v Pruto-Dnestrovskom mezhdurech'e. Stratum plus 1: 155-171. (in Russian)

Kulkova M. A. 2014. Radiouglerodnoye datirovaniye drevney keramiki. Samarskiy nauchnyy vestnik 3(8): 115122. (in Russian)

Kunikita D. and 11 co-authors. 2007. Analysis of radiocarbon dates of an archaeological site in the Russian Far East: The marine reservoir effect as seen on charred remains on pottery. Nuclear Instruments and Methods in Physics Research B259: 467-473.

https://doi.org/10.1016/j.nimb.2007.01.307

Larina 0. V. 1999. Kultura lineyno-lentochnoy keramiki pruto-dnestrovskogo regiona. Stratum plus 2: 10-140. (in Russian)

2006. Neoliticheskaya keramika poseleniya Tetereuka Noue XV (k probleme ischeznoveniya kul'tury lineynolentochnoy keramiki). Revista Arheologică $S . N$. II (1-2): 35-55. (in Russian)

Larina 0. V., Vekhler K.-P., Dergachev V. A., Kovalenko S. I., and Bikbaev V. M. 1997. Novye polevye issledovaniia pamiatnikov mezolita i neolita Moldovy. In V. Dergachev (ed.), Vestigii arheologice din Moldova. Chişinău: 62110. (in Russian)

Larina 0., Petrenko V., and Sapožnikov I. 1999. Materialul ceramic al culturii ceramicii bandliniare: Așesarea Mainova Balka din Ukraina. In T. Arnăut, A. Zanoci, S. Matveev (eds.), Studia in honorem Ion Niculită. Cartdidact. Chişinău: 21-34.

Lazarovici G. 1984. Neoliticul timpuriu în România. Acta Musei Porolissensis 8: 48-101. 
Lillie M. C., Budd C., Potekhina I., and Hedges R. 2009. The radiocarbon reservoir effect: new evidence from the cemeteries of the middle and lower Dnieper basin, Ukraine. Journal of Archaeological Science 36(2): 256264. https://doi.org/10.1016/j.jas.2008.09.005

Makkay J. 1990. The Protovinča Problem - as seen from the Northernmost Frontier. In D. Srejović, N. Tasić (eds.), Vinča and its World. International Symposium 'The Danubian region from 6000 to 3000 B.C.'. Serbian Academy of Science and Arts \& University of Belgrade, Faculty of Philosophy Centre for Archaeological Research. Belgrade: 113-122.

Makkay J., Kaczanowska M., Kozłowski J. K., Paluch T., Pap I., and Vörös I. 2007. The excavations of the Early Neolithic sites of the Körös Culture in the Körös Valley, Hungary: the final report. Vol. 1. The excavations: stratigraphy, structures and graves. Societá per la Preistoria e Protostoria della Regione Friuli-Venezia Giulia. Quaderni 11. Trieste.

Manko V. O. 2006. Neolit Pivdenno-Skhidnoi Ukrainy. Kamiana doba Ukrainy 9. Sliakh. Kyiv. (in Ukrainian)

2013. Finalnyi paleolit - neolit Krymu: kulturno-istorychnyi protses. 0. Filiuk. Kyiv. (in Ukrainian)

2016. Absolyutnoye datirovaniye nekotorykh neoliticheskikh kul'tur na territorii Ukrainy. In A. N. Mazurkevich, M. A. Kulkova, and E. V. Dolbunova (eds.), Radiouglerodnaya khronologiya epokhi neolita Vostochnoy Yevropy VII-III tys. do n. e. Svitok. Smolensk: 261279. (in Russian)

Mantu C.-M. 1995. Căteva considerații privind cronologia absolută a neo- eneoliticului din Romănia. Studii si cercetări de istorie veche şi arheologie 46(3-4): 213- 235.

Markevich V. I. 1973. Pamyatniki epohi neolita i eneolita. Arheologicheskaya karta MSSR 2. Shtiintsa. Kishinev. (in Russian)

1974. Bugo-dnestrovskaia kultura na territorii Moldavii. Shtiintsa Kishinev. (in Russian)

Mazurkevich A., Dolbunova E. 2015. The oldest pottery in hunter-gatherer communities and models of Neolithisation of Eastern Europe. Documenta Praehistorica 42: 13-66. https://doi.org/10.4312/dp.42.2

Petrenko V. G. 2012. Stoyanka Girzhevo: nekotoryye novyye i maloizvestnyye dannyye. In A. A. Prigarin (ed.), Chelovek v istorii i kulture 2. SMIL. Odessa: 228-239. (in Russian)

Philippsen B. 2015. Hard water and old food. The freshwater reservoir effect in radiocarbon dating of food resi- dues on pottery. Documenta Praehistorica 42: 159-170. https://doi.org/10.4312/dp.42.10

Piatnicková K. 2015. Eastern Linear Pottery Culture in the Western Tisza Region in Eastern Slovakia. Tiszadob Group as a Base of the Bükk Culture. In C. Virag (ed.), Neolithic cultural phenomena in the upper Tisza basin. International Conference: July 10-12, 2014, Satu Mare. Editura Muzeului Satmarean. Satu Mare: 161-183.

Piezonka H. 2015. Jäger, Fischer, Töpfer. Wildbeuter mit früher Keramik in Nordosteuropa im 6. Und 5. Jahrtausend v. Chr. Archäologie in Eurasien 30. Habelt. Bonn.

Popuşoi E. 2005. Trestiana. Monografie arheologică. Sfera. Bârlad.

Quitta H., Kohl G. 1969. Neue Radiocarbondaten zum Neolithicum und zur frühen Bronzezeit Südosteuropas und der Sowjetunion. Zeitschrift für Archäologie 3: 223255.

Rassamakin Yu. 2012. Absolute Chronology of Ukrainian Tripolian Settlements In F. Menotti, A. G. Korvin-Piotrovskiy (eds.), The Tripolye culture giant-settlements in Ukraine: formation, development and decline. Oxbow Books. Oxford: 19-69.

Reimer P. J. and 25 co-authors. 2013. IntCal13 and Marine13 Radiocarbon Age Calibration Curves 0-50,000 Years cal BP. Radiocarbon 55(4): 1869-1887.

https://doi.org/10.2458/azu_js_rc.55.16947

Reingruber A. 2016. A Network of the Steppe and Forest Steppe along the Prut and Lower Danube Rivers during the 6th Millennium BC. Documenta Praehistorica 43: 167-181. https://doi.org/10.4312/dp.43.8

2017. The Beginning of the Neolithic Way of Life in the Eastern Lower Danube Area: A View from the North. In A. Reingruber, Z. Tsirtsoni, and P. Nedelcheva (eds.), Going West? The Dissemination of Neolithic Innovations between the Bosporus and the Carpathians. Routledge, European Association of Archaeologists. London: 91-112.

2018. Changing perspectives: Looking at the Neolithic in the Northwest Pontic region through radiocarbon dates. In T. Kashuba and E. Kaiser (eds.), Principles and Methods of Dating in Archaeology (Neolithic Middle Ages). Institute for the History of Material Culture RAS. St. Petersburg: 81-96.

Sapozhnikov I. V., Sapoznikova G. V. 2005. Khronolohiia poselen ta kulturna poslidovnist mezolitu y neolitu Pivnichno-Zakhidnoho Prychornomoria. Kamiana doba Ukrainy 7: 87-95. (in Ukrainian) 
Stanko V. N. 1966. Mezoliticheskaya stoyanka Girzhevo v Odesskoy oblasti. Sovetskaya arkheologiya 2: 96-103. (in Russian)

1967. Nekotorye voprosy pozdnego mezolita SeveroZapadnogo Prichernomor'ya. Zapiski Odesskogo arkheologicheskogo obshchestva 2(35): 155-168. (in Russian)

Stanko V. N., Svezhencev Yu. S. 1988. Hronologiya i periodizaciya pozdnego paleolita i mezolita Severnogo Prichernomor'ya. Byulleten' komissii po izucheniyu chetvertichnogo perioda 57: 116-119. (in Russian)

Telegin D. Ya. 1977. Retsenziia na knyhu: V. I. Markevich. Bugo-dnestrovskaia kultura na territorii Moldavii. Arkheolohiia 23: 88-91. (in Ukrainian)

Telegin D. Ya., Kovaliukh N. N., Potekhina I. D., and Lillie M. 2000. Chronology of Mariupol type cemeteries and subdivision of the Neolithic - Copper Age cultures into periods for Ukraine. Radiocarbon and Archaeology 1: 59-74.

Thissen L. 2009. First ceramic assemblages in the Danube catchment, SE Europe - a synthesis of the radiocarbon evidence. Buletinul Muzeului Judeţean Teleorman. Seria Arheologie 1: 9-30.

Tovkajlo M. 1996. Periodisierung und Chronologie des Spätneolithikums in den Steppen am Südlichen Bug. Eurasia antiqua 2: 9-28.

Tovkaylo M. T. 2005. Neolit Stepovoho Pobuzhzhia. Kamiana doba Ukrainy 6. Shliakh. Kyiv. (in Ukrainian)

2010. Rannoneolitychnyi horyzont poselennia Gard i problema neolityzatsii Pivnichno-Zakhidnoho Nadchornomoria. Kamiana doba Ukrainy 13: 208-228. (in Ukrainian)

2012. Neolitychna keramika $\mathrm{z}$ domishkoiu cherepashkovykh rachkiv Ostracoda (do problemy pokhodzhennia kardiumnoi keramiky v Ukraini). Arkheolohiia 3: 27-36. (in Ukrainian)

2014. Neolitizaciya Yugo-Zapadnoy Ukrainy v svete novyh issledovaniy poseleniya Gard. Stratum plus 2: 183245. (in Russian)

Tringham R. 1971. Hunters, Fishers and Farmers of Eastern Europe (6000-3000 B. C.). Hutchinson University Press. London.

Tsetlin Yu. B. 1991. Periodizaciya neolita Verhnego Povolzh'ya. Metodicheskie problemy. Institut arheologii AN SSSR. Moskva. (in Russian)
Tsuneki A. 2012. Tell el-Kerkh as a Neolithic Mega Site. Orient 47: 29-66.

Ursulescu N. 1984. Evolutia culturii Starcevo-Cris pe teritoriul Moldovei. Muzeul Judeţean Suceava. Suceava.

Videiko M. Yu., Kovaliukh M. M. 1998. Izotopne datuvannia pamiatok buho-dnistrovskoi kultury. In D. N. Kozak, N. O. Havryliuk (eds.), Arkheolohichni vidkryttia v Ukraini 1997-1998 rr. Instytut arkheolohii Natsionalnoi akademii nauk Ukrainy. Kyiv: 65-66. (in Ukrainian)

Vybornov A. A. 2008. Neolit Volgo-Kam'ya. Izdatel'stvo Samarskogo gosudarstvennogo pedagogicheskogo universiteta. Samara. (in Russian)

Welcher K.P. 2001. Studien zum Neolithikum der osteuropäischen Steppe. Archäologie in Eurasien 12. Philipp von Zabern. Mainz am Rhein.

Wechler K.-P., Dergacev V., and Larina 0. 1998. Neue Forschungen zum Neolithikum Osteuropas. Ergebnise der moldavisch-deutschen Geländearbeiten 1995 und 1997. Prähistorische Zeitschrift 73(2): 151-166.

https://doi.org/10.1515/prhz.1998.73.2.151

Yanushevich Z. V. 1989. Agricultural evolution north of the Black Sea from the Neolithic to the Iron Age. In D. R. Harris, G. C. Hillman (eds.), Foraging and farming. Unwin Hyman. London; Boston: 607-619.

Yoshida K., Ohmichi J., Kinose M., Iijima H., Oono A., Abe N., Miyazaki Y., and Matsuzaki H. 2004. The application of ${ }^{14} \mathrm{C}$ dating to potsherds of the Jomon period. Nuclear Instruments and Methods in Physics Research B223224: 716-722. https://doi.org/10.1016/j.nimb.2004.04.133

Zaliznyak L. L., Manko V. 0. 2004. Stoianky bilia s. Dobrianka na r. Tikych ta deiaki problemy neolityzatsii Serednoho Podniprovia. Kamiana doba Ukrainy 5: 137-168. (in Ukrainian)

Zaliznyak L. L., Tovkaylo M. T., Manko V. O., and Sorokun A. A. 2013. Stoianky bilia khultora Dobrianka ta problema neolityzatsii Buho-Dniprovskoho mezhyrichchia. In L. L. Zaliznyak (ed.), Naidavnishe mynule Novomyrhorodshchyny. Kamiana doba Ukrainy 15. Sliakh. Kyiv: 194257. (in Ukrainian)

Zvelebil M., Rowley-Conwy P. 1984. Transition to farming in northern Europe: a hunter-gatherer perspective. Norwegian Archaeological Review 17: 104-128.

1986. Foragers and farmers in Atlantic Europe. In M. Zvelebil (ed.), Hunters in Transition: Mesolithic Societies of Temperate Eurasia and Their Transition to Farming. Cambridge University Press. Cambridge: 67- 93. 


\section{Appendix}

Tab. 1. The dates measured on samples from the BDC sites.

\begin{tabular}{|c|c|c|c|c|c|c|}
\hline Site & Context & Lab No & Material & $\begin{array}{c}14 \mathrm{C} \text { age } \\
\text { BP }\end{array}$ & $\begin{array}{c}\text { Calibrated age } \\
\text { cal BC }(2 \sigma)\end{array}$ & Reference \\
\hline Bazkiv Ostriv & $\begin{array}{l}\text { square } B^{\prime} / 8 \text {, } \\
\text { depth } 80 \mathrm{~cm}\end{array}$ & Ki-8166 & $\begin{array}{l}\text { animal bone - } \\
\text { 'bone polisher' }\end{array}$ & $7410 \pm 65$ & $6426-6100$ & $\begin{array}{l}\text { Kotova 2002.103; } \\
\text { Gaskevych 2017.200 }\end{array}$ \\
\hline Bazkiv Ostriv & $\begin{array}{l}\text { square JA/12, } \\
\text { depth } 80 \mathrm{~cm}\end{array}$ & Ki-8167 & $\begin{array}{l}\text { animal bone - } \\
\text { 'bone awl' (?) }\end{array}$ & $7270 \pm 70$ & $6336-6004$ & $\begin{array}{l}\text { Kotova 2002.103; } \\
\text { Gaskevych 2017.200 }\end{array}$ \\
\hline Bazkiv Ostriv & $\begin{array}{l}\text { square } G^{\prime} / 7, \\
\text { depth } 80 \mathrm{~cm}\end{array}$ & Ki-6651 & $\begin{array}{l}\text { animal bone - } \\
\text { 'boar tusk' (?) }\end{array}$ & $7235 \pm 60$ & $6224-6009$ & $\begin{array}{l}\text { Telegin et al. } 2000.64 ; \\
\text { Burdo } 2002.433\end{array}$ \\
\hline Bazkiv Ostriv & depth $90 \mathrm{~cm}$ & Ki-6696 & $\begin{array}{l}\text { animal bone - } \\
\text { 'boar tusk' }\end{array}$ & $7215 \pm 55$ & $6216-6002$ & $\begin{array}{l}\text { Telegin et al. } 2000.64 \\
\text { Burdo } 2002.432\end{array}$ \\
\hline Bazkiv Ostriv & $\begin{array}{l}\text { square } J U / 7 \\
\text { depth } 80 \mathrm{~cm}\end{array}$ & Ki-6652 & $\begin{array}{l}\text { animal bone - } \\
\text { 'bone polisher'(?) }\end{array}$ & $7160 \pm 55$ & $6207-5912$ & $\begin{array}{l}\text { Telegin et al. } 2000.63,64 ; \\
\text { Burdo } 2002.433\end{array}$ \\
\hline Bazkiv Ostriv & square $\mathrm{U} / 4$ & Ki-8168 & $\begin{array}{l}\text { animal bone - } \\
\text { 'antler hoe' }\end{array}$ & $6720 \pm 70$ & $5736-5514$ & $\begin{array}{l}\text { Kotova 2002.104; } \\
\text { Gaskevych 2017.200 }\end{array}$ \\
\hline Bazkiv Ostriv & $\begin{array}{l}\text { square } \check{S} / 14, \\
\text { depth } 60 \mathrm{~cm}\end{array}$ & Ki-8169 & $\begin{array}{l}\text { animal bone - } \\
\text { 'antler' }\end{array}$ & $6580 \pm 80$ & $5644-5374$ & $\begin{array}{l}\text { Kotova 2002.104; } \\
\text { Gaskevych 2017.200 }\end{array}$ \\
\hline$\overline{\text { Dobrianka-1 }}$ & & Ki-14798 & $\begin{array}{l}\text { organic inclu- } \\
\text { sions in pottery }\end{array}$ & $6880 \pm 90$ & $5978-5631$ & Manko 2013.216 \\
\hline Dobrianka-1 & & Ki-14799 & $\begin{array}{l}\text { organic inclu- } \\
\text { sions in pottery }\end{array}$ & $6730 \pm 90$ & $5786-5485$ & Manko 2013.216 \\
\hline$\overline{\text { Dobrianka-1 }}$ & & Ki-9833 & $\begin{array}{l}\text { organic inclu- } \\
\text { sions in pottery }\end{array}$ & $6530 \pm 140$ & $5714-5224$ & Manko 2006.17 \\
\hline$\overline{\text { Dobrianka-1 }}$ & & Ki-9834 & $\begin{array}{l}\text { organic inclu- } \\
\text { sions in pottery }\end{array}$ & $6360 \pm 150$ & $5616-4991$ & Zaliznyak, Manko 2004.141 \\
\hline$\overline{\text { Dobrianka-3 }}$ & $\begin{array}{l}\text { trench 3, } \\
\text { depth 1.om }\end{array}$ & OxA-17490 & $\begin{array}{l}\text { animal bone } \\
\text { (Bos primigenius) }\end{array}$ & $9115 \pm 45$ & $8454-8252$ & Lillie et al. 2009.260 \\
\hline Dobrianka-3 & & Ki-11105 & animal bone & $7400 \pm 130$ & $6474-6016$ & Zaliznyak, Manko 2004.145 \\
\hline Dobrianka-3 & & Ki-11104 & animal bone & $7320 \pm 130$ & $6441-5933$ & Zaliznyak, Manko 2004.145 \\
\hline Dobrianka-3 & $\begin{array}{l}\text { trench } 3, \\
\text { depth } 1.2 \mathrm{~m}\end{array}$ & $\begin{array}{l}\text { OxA-X- } \\
2222-33\end{array}$ & human bone & $7297 \pm 39$ & $6230-6070$ & Lillie et al. 2009.260 \\
\hline Dobrianka-3 & & Ki-11108 & $\begin{array}{l}\text { organic inclu- } \\
\text { sions in pottery }\end{array}$ & $7260 \pm 170$ & $6452-5808$ & Zaliznyak, Manko 2004.145 \\
\hline Dobrianka-3 & & Ki-11106 & $\begin{array}{l}\text { organic inclu- } \\
\text { sions in pottery }\end{array}$ & $7070 \pm 150$ & $6232-5668$ & Zaliznyak, Manko 2004.145 \\
\hline Dobrianka-3 & & Ki-11107 & $\begin{array}{l}\text { organic inclu- } \\
\text { sions in pottery }\end{array}$ & $7050 \pm 160$ & $6232-5642$ & Zaliznyak, Manko 2004.145 \\
\hline Dobrianka-3 & & Ki-11103 & animal bone & $7030 \pm 120$ & $6202-5670$ & Zaliznyak, Manko 2004.145 \\
\hline Dobrianka-3 & & GrA-33115 & animal bone & $4400 \pm 35$ & $3308-2910$ & Biagi et al. 2007.27 \\
\hline Dobrianka-3 & & GrA-33117 & animal bone & $3595 \pm 35$ & $2113-1831$ & Biagi et al. 2007.27 \\
\hline Gard & $\begin{array}{l}\text { square IX-9, } \\
\text { depth } 1.4^{-1.5 \mathrm{~m}}\end{array}$ & Ki-14796* & animal bone & $7640 \pm 90$ & $6655-6264$ & Tovkaylo 2010.Tab. 2 \\
\hline$\overline{\text { Gard }}$ & $\begin{array}{l}\text { square IV-100, } \\
\text { depth } 1.4-1.5 \mathrm{~m}\end{array}$ & Ki-14797 & $\begin{array}{l}\text { 'Early Neolithic } \\
\text { layer' soil }\end{array}$ & $6980 \pm 80$ & $6006-5723$ & Tovkaylo 2010.Tab. 2 \\
\hline$\overline{\text { Gard }}$ & $\begin{array}{l}\text { square IX-16, } \\
\text { depth } 1.3-1.4 \mathrm{~m}\end{array}$ & Ki-14791 & $\begin{array}{l}\text { organic inclusions } \\
\text { in the 'late' BDC } \\
\text { pottery }\end{array}$ & $6710 \pm 80$ & $5734-5489$ & Tovkaylo 2010.Tab. 2 \\
\hline Gard & $\begin{array}{l}\text { square IX-16, } \\
\text { depth } 1.3-1.4 \mathrm{~m}\end{array}$ & Ki-14790 & $\begin{array}{l}\text { organic inclusions } \\
\text { in the 'early' BDC } \\
\text { pottery with sand } \\
\text { and granules } \\
\text { admixture }\end{array}$ & $6630 \pm 90$ & $5721-5385$ & Tovkaylo 2010.Tab. 2 \\
\hline$\overline{\text { Gard }}$ & $\begin{array}{l}\text { square IX-39, } \\
\text { depth } 1.1-1.2 \mathrm{~m}\end{array}$ & Ki-14789 & $\begin{array}{l}\text { organic inclusions } \\
\text { in the 'early' BDC } \\
\text { pottery with coarse } \\
\text { shell fragments } \\
\text { admixture }\end{array}$ & $6480 \pm 80$ & $5612-5310$ & Tovkaylo 2010.Tab. 2 \\
\hline
\end{tabular}




\begin{tabular}{|c|c|c|c|c|c|c|}
\hline Site & Context & Lab No & Material & $\begin{array}{c}{ }^{14} \mathrm{C} \text { age } \\
\text { BP }\end{array}$ & $\begin{array}{l}\text { Calibrated age } \\
\text { cal BC }(2 \sigma)\end{array}$ & Reference \\
\hline$\overline{\text { Gard }}$ & $\begin{array}{l}\text { square IX-29, } \\
\text { depth } 1.2-1.3 \mathrm{~m}\end{array}$ & Ki-14792 & $\begin{array}{l}\text { organic inclusions } \\
\text { in the 'late' BDC } \\
\text { pottery with Ostra- } \\
\text { cods admixture }\end{array}$ & $6520 \pm 80$ & $5618-5338$ & Tovkaylo 2010.Tab. 2 \\
\hline$\overline{\text { Gard }}$ & $\begin{array}{l}\text { square IV-70, } \\
\text { depth } 1.2-1.3 \mathrm{~m}\end{array}$ & Ki-14793 & $\begin{array}{l}\text { organic inclusions } \\
\text { in the 'late' BDC } \\
\text { pottery }\end{array}$ & $6400 \pm 90$ & $5546-5210$ & Tovkaylo 2010.Tab. 2 \\
\hline$\overline{\text { Gard }}$ & $\begin{array}{l}\text { square IV-97, } \\
\text { depth } 1.2-1.3 \mathrm{~m}\end{array}$ & Ki-14794 & $\begin{array}{l}\text { organic inclusions } \\
\text { in the Trypillia A } \\
\text { pottery }\end{array}$ & $6360 \pm 80$ & $5486-5080$ & Tovkaylo 2010.Tab. 2 \\
\hline Gard & $\begin{array}{l}\text { square IV-87, } \\
\text { depth } 1.2-1.3 \mathrm{~m}\end{array}$ & Ki-14795 & $\begin{array}{l}\text { organic inclusions } \\
\text { in the Trypillia A } \\
\text { pottery }\end{array}$ & $6170 \pm 80$ & $5312-4910$ & Tovkaylo 2010.Tab. 2 \\
\hline Gard III & square 8 & Ki-6655 & animal bone & $6930 \pm 55$ & $5976-5716$ & Telegin et al. 2000.64 \\
\hline Gard III & & Ki-6650 & animal bone & $6865 \pm 50$ & $5875-5650$ & Telegin et al. 2000.63 \\
\hline Gard III & trench 7 & Ki-6687 & animal bone & $6640 \pm 50$ & $5636-5486$ & Telegin et al. 2000.64 \\
\hline Hirzhove & $\begin{array}{l}\text { trench IV, } \\
\text { spit } 1\end{array}$ & Ki-11240 & $\begin{array}{l}\text { animal bone } \\
\text { (Bos or Equus) }\end{array}$ & $7390 \pm 100$ & $6435-6065$ & Manko 2006.19 \\
\hline Hirzhove & $\begin{array}{l}\text { trench II, } \\
\text { spit } 1\end{array}$ & Ki-11241 & $\begin{array}{l}\text { organic inclusions } \\
\text { in pottery }\end{array}$ & $7280 \pm 170$ & $6465-5812$ & Manko 2006.19 \\
\hline Hirzhove & $\begin{array}{l}\text { trench II, } \\
\text { spit } 1\end{array}$ & $\mathrm{Ki}-11743^{* k *}$ & $\begin{array}{l}\text { organic inclusions } \\
\text { in pottery }\end{array}$ & $7200 \pm 220$ & $6466-5668$ & Manko 2006.19 \\
\hline Hirzhove & & Le-1703 & animal bone & $7050 \pm 60$ & $6032-5789$ & Stanko, Svezhentsev 1988.117 \\
\hline $\begin{array}{l}\text { Melnychna } \\
\text { Krucha }\end{array}$ & $\begin{array}{l}2012 \text {, the base } \\
\text { of stratigraphi- } \\
\text { cal unit } 3 \\
\text { depth } 200 \mathrm{~cm}\end{array}$ & Poz-67496 & $\begin{array}{l}\text { charcoal } \\
\text { (Angiosperm) }\end{array}$ & $7520 \pm 50$ & $6461-6252$ & Kiosak, Salavert 2018.122 \\
\hline $\begin{array}{l}\text { Melnychna } \\
\text { Krucha }\end{array}$ & $\begin{array}{l}2012 \text {, the base } \\
\text { of stratigra- } \\
\text { phical unit } 2\end{array}$ & Poz-67497 & charcoal (Fraxinus) & $7380 \pm 40$ & $6380-6100$ & Kiosak, Salavert 2018.122 \\
\hline $\begin{array}{l}\text { Mykolyna } \\
\text { Broiaka }\end{array}$ & $\begin{array}{l}\text { square } 1, \\
\text { depth } 120 \mathrm{~cm}\end{array}$ & Ki-8171 & animal bone & $6520 \pm 70$ & $5618-5356$ & Kotova 2002.104 \\
\hline Mytkiv Ostriv & depth $125 \mathrm{~cm}$ & Ki-6695 & animal bone & $7375 \pm 60$ & $6388-6090$ & Telegin et al. 2000.64 \\
\hline Pechera I & & Ki-6693 & animal bone & $7305 \pm 50$ & $6328-6054$ & Telegin et al. 2000.64 \\
\hline Pechera I & & Ki-6692 & animal bone & $7260 \pm 65$ & $6240-6008$ & Telegin et al. 2000.64 \\
\hline Pechera I & $\begin{array}{l}\text { square } \tilde{Z} / 7 \text {, } \\
\text { depth } 70 \mathrm{~cm}\end{array}$ & Ki-8164 & animal bone & $7205 \pm 70$ & $6227-5930$ & Kotova 2002.103 \\
\hline Puhach II & $\begin{array}{l}\text { trench } 2 \text {, } \\
\text { depth } 2.5-2.6 \mathrm{~m}\end{array}$ & Ki-6656 & animal bone & $6895 \pm 50$ & $5890-5674$ & Telegin et al. 2000.63 \\
\hline Puhach II & square $X I X-51$ & Ki-6657 & animal bone & $6810 \pm 60$ & $5836-5622$ & Telegin et al. 2000.63 \\
\hline Puhach II & & Ki-6649 & animal bone & $6780 \pm 50$ & $5752-5616$ & Telegin et al. 2000.63 \\
\hline Puhach II & & Ki-6648 & animal bone & $6740 \pm 65$ & $5741-5534$ & Telegin et al. 2000.63 \\
\hline Puhach II & $\begin{array}{l}\text { trench 1, } \\
\text { depth } 2.8-2.9 \mathrm{~m}\end{array}$ & Ki-6679 & animal bone & $6560 \pm 50$ & $5621-5390$ & Telegin et al. 2000.64 \\
\hline Puhach II & $\begin{array}{l}\text { trench } 1, \\
\text { depth } 2.4-2.5 \mathrm{~m}\end{array}$ & Ki-6678 & animal bone & $6520 \pm 60$ & $5615-5363$ & Telegin et al. 2000.64 \\
\hline Puhach II & & $\mathrm{Ki}-303 \mathrm{O}$ & charcoal & $5920 \pm 60$ & $4962-4619$ & Tovkajlo 1996.24 \\
\hline Savran & & Ki-6654 & animal bone & $6985 \pm 60$ & $5986-5744$ & Telegin et al. 2000.64 \\
\hline Savran & "dwelling" 2 & Ki-6653 & animal bone & $6920 \pm 50$ & $5969-5716$ & Telegin et al. 2000.64 \\
\hline Sokiltsi I & Complex 1 & Ki-8165 & animal bone & $7260 \pm 80$ & $6350-5988$ & Kotova 2002.103 \\
\hline Sokiltsi II & depth $140 \mathrm{~cm}$ & Ki-6697 & animal bone & $7470 \pm 60$ & $6438-6232$ & Telegin et al. 2000.64 \\
\hline Sokiltsi II & depth $120 \mathrm{~cm}$ & Ki-6698 & animal bone & $7405 \pm 55$ & $6416-6102$ & Telegin et al. 2000.64 \\
\hline Soroca II & layer 3 & $B \ln -588 *$ & charcoal (Fraxinus sp.) & $7515 \pm 120$ & $6596-6099$ & Quitta, Kohl, 1969.250 \\
\hline Soroca II & layer 2 & $B \ln -587^{*}$ & charcoal (Ulmus sp.) & $7420 \pm 80$ & $6435-6097$ & Quitta, Kohl, 1969.250 \\
\hline Soroca II & $\begin{array}{l}\text { 1964, from pit } \\
\text { within upper } \\
\text { layer I; depth } \\
3.3-3.5 \mathrm{~m}\end{array}$ & Bln-586 & $\begin{array}{l}\text { charcoal } \\
\text { (Fraxinus sp.) }\end{array}$ & $6830 \pm 150$ & $5998-5491$ & Quitta, Kohl, 1969.250 \\
\hline
\end{tabular}




\begin{tabular}{|c|c|c|c|c|c|c|}
\hline Site & Context & Lab No & Material & $\begin{array}{c}{ }^{14} \mathrm{C} \text { age } \\
\text { BP }\end{array}$ & $\begin{array}{c}\text { Calibrated age } \\
\text { cal BC }(2 \sigma)\end{array}$ & Reference \\
\hline Soroca III & & KiA-4159 & horse tooth & $9950 \pm 70$ & $9758-9713$ & Wechler 2001.29 \\
\hline Soroca III & & Gd-11297 & shell & $8430 \pm 90$ & $7602-7192$ & Wechler 2001.29 \\
\hline Soroca III & & ?? & ?? & $6750 \pm 100$ & $5840-5488$ & Yanushevich 1989.609 \\
\hline Soroca III & & KiA-4158 & deer bone & $5560 \pm 60$ & $4526-4273$ & Wechler 2001.29 \\
\hline Soroca V & $\begin{array}{l}1966, \text { from } \\
\text { fireplace at } \\
2 \mathrm{~m} \text { depth }\end{array}$ & Bln-589 & $\begin{array}{l}\text { charcoal } \\
\text { (Fraxinus sp.) }\end{array}$ & $6495 \pm 100$ & $5631-5235$ & Quitta, Kohl 1969.250 \\
\hline Tashlyk II & $\begin{array}{l}\text { square III-23, } \\
\text { depth } 2.34 \mathrm{~m}\end{array}$ & Ki-10789 & animal bone & $6160 \pm 60$ & $5292-4948$ & Fomenko et al. 2014.Tab. 3 \\
\hline $\begin{array}{l}\text { Tătărăuca } \\
\text { Nouă XIV }\end{array}$ & & Gd-9697 & animal bone & $5370 \pm 170$ & $4548-3796$ & Wechler 2001.29 \\
\hline $\begin{array}{l}\text { Tătărăuca } \\
\text { Nouă XV }\end{array}$ & $\begin{array}{l}\text { square D26 } \\
\text { "bottom" (on } \\
\text { shell midden } \\
\text { 10), depth } 1.10 \mathrm{~m}\end{array}$ & $\begin{array}{l}\mathrm{KiA}-3705 \mathrm{~b} \\
\ldots * * * \\
\mathrm{~m}\end{array}$ & food crust & $6340 \pm 70$ & $5478-5081$ & Wechler 2001.30 \\
\hline $\begin{array}{l}\text { Tătărăuca } \\
\text { Nouă XV }\end{array}$ & $\begin{array}{l}\text { square D26 } \\
\text { "bottom" (on } \\
\text { shell midden } \\
\text { 10), depth } 1.10 \mathrm{~m}\end{array}$ & $\begin{array}{l}\text { KiA-3705a } \\
m\end{array}$ & food crust & $5960 \pm 230$ & $5366-4362$ & Wechler 2001.30 \\
\hline $\begin{array}{l}\text { Tătărăuca } \\
\text { Nouă XV }\end{array}$ & $\begin{array}{l}\text { square E15, } \\
\text { depth } 1.25 \mathrm{~m} \text {, } \\
\text { within shell } \\
\text { midden }\end{array}$ & KiA-416o & antler & $5900 \pm 40$ & $4882-4690$ & Wechler 2001.30 \\
\hline $\begin{array}{l}\text { Tătărăuca } \\
\text { Nouă XV }\end{array}$ & & Gd-9693 & animal bone & $5220 \pm 70$ & $4242-3811$ & Wechler 2001.29 \\
\hline Ziankivtsi II & & Ki-6694* & animal bone & $7540 \pm 65$ & $6494-6244$ & Telegin et al. 2000.64 \\
\hline $\begin{array}{l}* \\
* * * \\
* * * * \\
\text { dark shading }\end{array}$ & \multicolumn{6}{|c|}{$\begin{array}{l}\text { - dates, which were originally linked with the Final Mesolithic (or "Pre-Pottery Ne } \\
\text { - repeated dating of sample Ki-11241 } \\
\text { - repeated dating of sample KiA-3705a } \\
\text { - too high or low dates, which are considered 'non-Neolithic' without discussion }\end{array}$} \\
\hline
\end{tabular}

\begin{tabular}{|c|c|c|c|c|c|c|c|}
\hline Autor & & & Period & and phase & & & \\
\hline & & Early & & Devel & loped & & ate \\
\hline Valentyn Danylenko $(1909.48,49)$ & Ziankivtsi & Skybyntsi & Sokiltsi & Pechera & Samchyntsi & Savran & Khmilnyk \\
\hline Viacheslav Markevich (1974.136-141) & 1 & II & & III & IV & $\mathrm{V}$ & - \\
\hline Ruth Tringham (1971.97) & - & & Early & & Middle & & Late \\
\hline Dmytro Telehin (1977.90) & - & & Pechera & & Samchyntsi & Savran & - \\
\hline Klaus-Peter Wechler (2001.30-31) - Dnister & - & & Early & & Late & & - \\
\hline Klaus-Peter Wechler (2001.52-54) - S. Buh & - & & Early & & Middle | & $\mathrm{L}$ & Late \\
\hline Nadiia Kotova (2002.19-21) & - & & Early & & Late & & - \\
\hline Mykola Tovkailo (2014.235-239) & $\mid$ Pre-Pottery & & Early & & Middle & $\mathrm{L}$ & Late \\
\hline
\end{tabular}

Tab. 2. Comparing of the BDC periodization schemes. 


\begin{tabular}{|c|c|c|c|c|c|c|}
\hline $\begin{array}{l}\text { Sample } \\
\text { No. }\end{array}$ & $\begin{array}{c}\text { Sample } \\
\text { weight (mg) }\end{array}$ & $\begin{array}{c}\text { Residue after AAA } \\
\text { treatment (mg) }\end{array}$ & $\begin{array}{c}\text { Residue after AAA } \\
\text { treatment (\%) }\end{array}$ & $\begin{array}{l}\text { Oxidation } \\
\text { weight (mg) }\end{array}$ & $\begin{array}{c}\mathrm{CO}_{2} \text { weight } \\
\text { (mg) }\end{array}$ & $\begin{array}{c}\mathrm{CO}_{2} \text { content } \\
(\%)\end{array}$ \\
\hline Shum-1c & 5.3 & 1.5 & 27.8 & 1.5 & 0.7 & 49.0 \\
\hline Shum-1t & 188.5 & 93.4 & 49.6 & 66.1 & 2.3 & 3.5 \\
\hline Hlyn-2t & 233.5 & 132.4 & 56.7 & 77.7 & 0.9 & 1.1 \\
\hline Hlyn-3t & 291.2 & 207.1 & 71.1 & 100.0 & 0.6 & 0.6 \\
\hline Bazk-4t & 257.5 & 164.5 & 63.9 & 53.0 & 0.4 & 0.7 \\
\hline Bazk-5t & 273.9 & 195.0 & 71.2 & 91.8 & 1.0 & 1.1 \\
\hline Bazk-6t & 211.6 & 127.9 & 60.4 & 83.7 & 2.0 & 2.4 \\
\hline Bazk-7t & 324.4 & 223.3 & 68.8 & 97.6 & 0.7 & 0.7 \\
\hline Bazk-8t & 229.0 & 122.1 & 53.3 & 84.7 & 1.0 & 1.1 \\
\hline Bazk-9c & 7.8 & 2.6 & 33.0 & 0.8 & 0.2 & 21.3 \\
\hline Bazk-9t & 197.1 & 99.6 & 50.5 & 66.2 & 3.7 & 5.6 \\
\hline
\end{tabular}

Tab. 3. Chemical treatments of the samples.

\begin{tabular}{|c|c|c|c|c|c|c|c|}
\hline $\begin{array}{l}\text { Sample } \\
\text { No }\end{array}$ & $\begin{array}{c}\text { Vessel } \\
\text { No }\end{array}$ & Figure & Material & $\begin{array}{l}{ }^{14 C} \text { age } \\
\text { BP }(1 \sigma)\end{array}$ & $\begin{array}{c}\text { Calibrated age } \\
\text { cal BC }(2 \sigma)\end{array}$ & Lab No & $\begin{array}{c}\delta^{13 C} \\
(\% \circ, \text { AMS })\end{array}$ \\
\hline \multicolumn{8}{|c|}{ Shumpliv-Cherniatka } \\
\hline Shum-1c & - & 2 & Charred residues (inner) & $5725 \pm 30$ & $4683-4491$ & TKA-20826 & $-23.6 \pm 0.2$ \\
\hline Shum-1t & - & 2 & Organic inclusions in the pottery paste & $5805 \pm 25$ & $4723-4558$ & TKA-20827 & $-29.5 \pm 0.2$ \\
\hline \multicolumn{8}{|l|}{ Hlynske I } \\
\hline Hlyn-2t & 16 & 4 & Organic inclusions in the pottery paste & $7080 \pm 30$ & $6016-5899$ & TKA-20828 & $-24.2 \pm 0.3$ \\
\hline Hlyn-3t & 7 & 5 & Organic inclusions in the pottery paste & $7795 \pm 30$ & $6686-6532$ & TKA-21090 & $-22.7 \pm 0.5$ \\
\hline \multicolumn{8}{|c|}{ Bazkiv Ostriv } \\
\hline Bazk-4t & 23 & 8 & Organic inclusions in the pottery paste & $7710 \pm 25$ & $6597-6477$ & TKA-20829 & $-25.8 \pm 0.4$ \\
\hline Bazk-5t & 1 & 9 & Organic inclusions in the pottery paste & $6855 \pm 30$ & $5807-5666$ & TKA-20830 & $-26.4 \pm 0.5$ \\
\hline Bazk-6t & 22 & 10 & Organic inclusions in the pottery paste & $6625 \pm 25$ & $5621-5514$ & TKA-20831 & $-28.4 \pm 0.2$ \\
\hline Bazk-7t & 21 & 11 & Organic inclusions in the pottery paste & $6970 \pm 25$ & $5972-5769$ & TKA-20832 & $-24.8 \pm 0.3$ \\
\hline Bazk-8t & 2 & 12 & Organic inclusions in the pottery paste & $6190 \pm 35$ & $5288-5030$ & TKA-20833 & $-24.0 \pm 0.6$ \\
\hline Bazk-gt & 39 & 13 & Organic inclusions in the pottery paste & $6040 \pm 25$ & $5211-5000$ & TKA-20834 & $-28.2 \pm 0.3$ \\
\hline Bazk-9c & 39 & 13 & Charred residues (inner) & $6145 \pm 35$ & $5003-4847$ & TKA-21091 & $-23.0 \pm 0.4$ \\
\hline
\end{tabular}

Tab. 4. Radiocarbon ages of the samples.

\begin{tabular}{|c|c|c|c|c|c|c|}
\hline $\begin{array}{l}\text { Sample } \\
\text { No }\end{array}$ & $\begin{array}{l}\text { Calibrated age } \\
\text { cal BC (2б) }\end{array}$ & Vessel No & Pottery type & Shell & $\begin{array}{l}\text { Waterworn sand } \\
\text { and gravel }\end{array}$ & Impressions of algae? \\
\hline \multicolumn{7}{|c|}{ Shumyliv-Cherniatka } \\
\hline Shum-1c & $4683-4491$ & \multirow{2}{*}{-} & \multirow{2}{*}{ Savran } & \multirow{2}{*}{+} & \multirow{2}{*}{-} & \multirow{2}{*}{+} \\
\hline Shum-1t & $4723-4558$ & & & & & \\
\hline \multicolumn{7}{|c|}{ Hlynske I } \\
\hline Hlyn-2t & $6016-5899$ & 16 & Pechera-Kriş ? & - & - & - \\
\hline Hlyn-3t & $6686-6532$ & 7 & Pechera-Skybyntsi? & + & - & + \\
\hline \multicolumn{7}{|c|}{ Bazkiv Ostriv } \\
\hline Bazk-4t & $6597-6477$ & 23 & Skybyntsi & + & + & + \\
\hline Bazk-5t & $5807-5666$ & 1 & Samchyntsi & - & + & + \\
\hline Bazk-6t & $5621-5514$ & 22 & Skybyntsi & + & - & + \\
\hline Bazk-7t & $5972-5769$ & 21 & Skybyntsi & + & + & + \\
\hline Bazk-8t & $5288-5030$ & 2 & Samchyntsi & - & - & + \\
\hline Bazk-9c & $5003-4847$ & \multirow{2}{*}{39} & \multirow{2}{*}{ Samchyntsi } & \multirow{2}{*}{-} & \multirow{2}{*}{-} & \multirow{2}{*}{+} \\
\hline Bazk-gt & $5211-5000$ & & & & & \\
\hline
\end{tabular}

Tab. 5. Admixtures of possible aquatic origin in the pottery paste of dated vessels. 